\title{
NEOTECTÔNICA DA REGIÃO AMAZÔNICA: ASPECTOS TECTÔNICOS, GEOMORFOLÓGICOS E DEPOSICIONAIS
}

\author{
João Batista Sena Costa (*), Ruth Léa Bemerguy (*), Yociteru Hasui (**), \\ Maurício da Silva Borges (*), Carlos Roberto Paranhos Ferreira Júnior (***), \\ Pedro Édson Leal Bezerra (****), Marcondes Lima da Costa $(*)$ \\ \& Jane Maria Garrafielo Fernandes $(*)$
}

\begin{abstract}
Several types of structures are observed in the Precambrian, Mesozoic and Cenozoic rocks of the Amazon region, which represent the major features of the neotectonic framework developed since the Miocene. They controlled the sediment deposition of the Upper Tertiary and Quaternary, as well as have influenced the development of the present landform patterns and drainage systems. Transpressive and transtensive areas are recognized based on their nature and geometry, and related to two main episodes of transcurrent displacement of Miocene/Pliocene and Upper Pleistocene /Recent ages. Sets of E-W, ENEWSW and NE-SW right-hand strike-slip faults are present in most of these areas. These sets are linked by normal faults trending NW-SE and NNW-SSE, or by thrust faults trendig NE-SW and ENE-WSW, depending upon their geometry. Large areas with N-S trending younger normal faults are also observed. Earthquakes, the phenomenon of "fallen lands", fluvial channels migration, hot springs, etc., are related to areas where some of these faults remain active. All these structures are related to an intraplate E-W righthand shear system induced by the rotation of South American Plate towards west.
\end{abstract}

\section{INTRODUÇÃO}

A neotectônica da região amazônica é marcada por estruturas, seqüências sedimentares, padrões de rede de drenagem e sistemas de relevo, cujas características vêm sendo gradativamente desvendadas.

As informações remontam àquelas pioneiras de Sternberg (1950, 1953), colhidas nas adjacências da cidade de Manaus, assinalando a presença de lineamentos que controlam parte da rede de drenagem atual, a incidência de terremotos em amplas áreas e o desenvolvimento de falésias (fenômenos das "terras caídas") sob controle de falhas nas margens dos principais rios.

Posteriormente, deve-se ao Projeto Radam o primeiro mapeamento em nível de reconhecimento e um apanhado regional da paisagem e seus elementos, divulgados nos primeiros volumes da série Levantamento de Recursos Naturais.

A partir da década de 80 , foram publicados vários estudos sobre aspectos diversos de muitas outras áreas da região amazônica, notadamente por Franzinelli \& Piuci (1980), Eiras \& Kinoshita (1988), Franzinelli \& Igreja (1990), Cunha (1991), Bemerguy \& J.B.S. Costa (1991), J.B.S. Costa et al. (1993, 1994, 1995), Fernandes Filho et al. (1995), Bemerguy et al. (1995), Borges et al. (1995a, b) e Ferreira Jr. et al. (1996). Também resultados de interpretação de linhas sísmicas obtidas pela Petrobrás foram divulgados principalmente por Eiras \& Kinoshita (1988) e Travassos \& Barbosa Filho (1990) e os dados sismológicos, que assinalam movimentação atual em diversas áreas, foram sistematizados mais recentemente por Mioto (1993).

Dez áreas selecionadas dos estados do Amazonas, Roraima, Amapá, Pará, Maranhão e Tocantins (Figura 1) foram estudadas em seus aspectos morfo-litoestruturais pelos autores e resultados parciais foram apresentados ao longo dos últimos anos. Um primeiro ensaio de síntese foi divulgado por J.B.S. Costa (1996), em palestra no recente V Simpósio de Geologia da Amazônia e este artigo sintetiza as informações acumuladas, procurando delinear a evolução geológica da região amazônica na sua etapa mais recente, vinculada à Neotectônica.

Antes de expor os dados e interpretações, um aspecto importante a se firmar é o do entendimento que se tem da Neotectônica e da época de seu início.

Na região amazônica, as seqüências sedimentares do Terciário Inferior aparecem sobretudo nas bacias do Amazonas (Formação Alter do Chão), Marajó (parte da Sequiência Pós-Rifte) e Parnaíba (Formação Ipixuna), representando os registros das últimas manifestações do Evento Sul-Atlantiano, de caráter extensional, nesse domínio continental intraplaca. Nessas unidades e outras mais antigas desenvolveu-se um perfil laterítico maturo (Truckenbrodt et al. 1991, M.L. Costa 1991), atribuído ao Eoceno-Oligoceno, marcando importante período de estabilidade tectônica.

Em seguida sobrevieram processos de estruturação, morfogênese e sedimentação até hoje em vigor, relacionados com a incidência da Neotectônica, cujo regime tectônico é do tipo transcorrente. Dois pulsos 


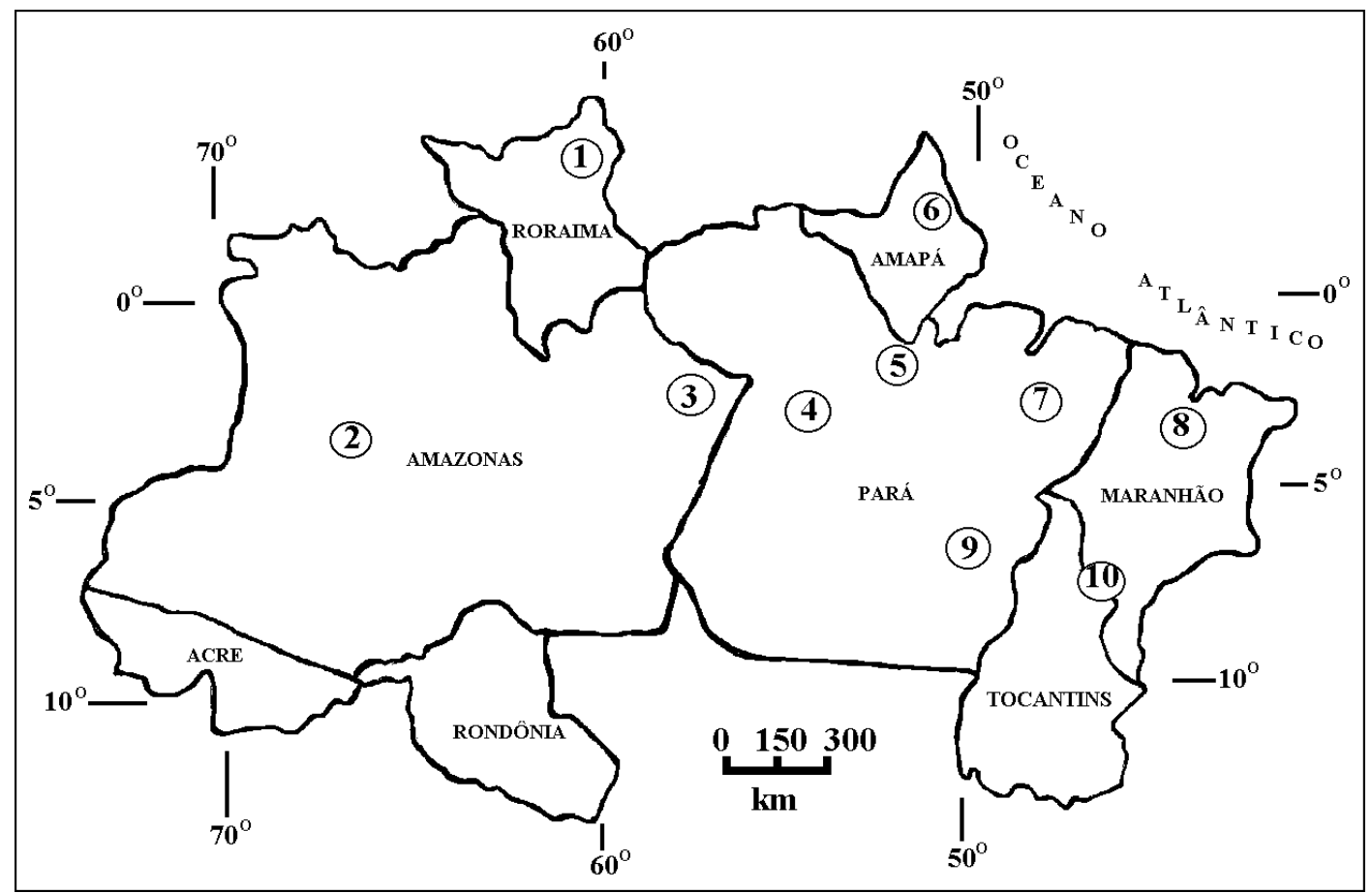

Figura 1: Localização das áreas abordadas.

A configuração de cada área é mostrada nas figuras 3 a 13.

Figure 1: Localization of the study areas. Figures 3 to 13 show the neotectonic structures for each area.

de movimentação transcorrente são reconhecidos, do Mioceno/Plioceno e do Pleistoceno Superior/Recente, a eles se relacionando deslocamentos ao longo de feixes de falhas, geração de depósitos sedimentares e controle de padrões de drenagem e sistemas de relevo (J.B.S. Costa et al. 1994, 1995; Fernandes Filho et al. 1995; Bemerguy et al. 1995; Borges et al. 1995a, b; Ferreira Jr. et al. 1996).

Assim, reconhece-se um evento tectônico correspondente ao Evento Sul-Atlantiano (Schobbenhaus \& Campos 1984) ou Reativação Wealdeniana (Almeida 1967), do Mesozóico/Paleogeno, caracterizado pelo regime extensional, e outro correspondente à Neotectônica, do Mioceno/Recente, marcado por regime de tipo transcorrente, como reconhecido anteriormente por Hasui (1990).

\section{UNIDADES LITO-ESTRATIGRÁFICAS}

As unidades lito-estratigráficas do intervalo Mioceno-Recente, de interesse aqui por guardarem íntima relação com os movimentos tectônicos do Terciário Superior e Quaternário, são representadas pelas formações Solimões, Pirabas e Boa Vista, e pelo Grupo Barreiras, bem como pelas formações lateríticas, além de diversas seqüências do Quaternário. O embasamento dessas unidades é representado pelas rochas do PréCambriano, Paleozóico, Mesozóico e do início do Cenozóico.

A Formação Solimões (Mioceno-Plioceno) cobre grande extensão no Estado do Acre e na parte oeste do Estado do Amazonas, guardando relação de discordância sobre a Formação Alter do Chão (Santos 1984). Reúne essencialmente argilitos e siltitos finamente laminados e maciços, contendo lentes de linhito e turfa, concreções carbonáticas e gipsíferas, além de quantidades menores de sedimentos arenosos. Essa unidade alcança $1.800 \mathrm{~m}$ de espessura, tem conteúdo fossilífero expressivo e seu desenvolvimento é relacionado com sistemas flúviolacustres.

A Formação Pirabas ocorre na região nordeste do Pará em afloramentos descontínuos no meio dos sedimentos do Grupo Barreiras e dos depósitos quaternários, destacando-se aqueles da Ilha de Fortaleza, no Município de São João de Pirabas, e das jazidas da CIBRASA, no Município de Capanema. Em sua constituição inclui margas acinzentadas friáveis seguidas de níveis de calcário fossilífero alternados com margas; há também registros de argilitos laminados, calcarenitos estratificados, calcários maciços e biocalciruditos. O conteúdo fossilífero sugere que esses sedimentos se formaram em condições de ambiente marinho raso/ lagunar/mangue no Eo-Mioceno.

O Grupo Barreiras (Mioceno-Pleistoceno) tem ampla distribuição no litoral norte do Brasil e apresenta grande variação faciológica, dominando as fácies argilosa com laminação plano-paralela, argilo-arenosa com estruturas wave e linsen, arenosa com estratificação sigmoidal, e arenosa com estratificação cruzada acanalada. Os tipos de estruturas sedimentares e as características das fácies indicam que esses sedimentos se desenvolveram em ambiente de planície de maré/estuário/plataforma interna, com importantes oscilações do nível do mar em um contexto regressivo (J.B.S. Costa et al. 1993). 
A Formação Boa Vista (incluindo a Formação Viruaquim) ocupa vasta área na região nordeste de Roraima, compreendendo essencialmente arenitos com intercalações de siltitos, além de níveis de argilitos, provavelmente depositados em sistemas flúviolacustres. As informações litológicas disponíveis são ainda de reconhecimento, parecendo que a unidade alcança espessura máxima da ordem de $100 \mathrm{~m}$ e se formou a partir do Terciário Superior em uma bacia com mais de $30.000 \mathrm{~km}^{2}$.

As formações lateríticas são enfatizadas no item seguinte por sua importância como horizontes de referência para os estudos neotectônicos.

As seqüências quaternárias incluem em essência depósitos sedimentares pelíticos a psamíticos, e em parte rudíticos, ligados à evolução dos sistemas de drenagem e do litoral. Os depósitos fluviais são aqueles de terraços, canais e de planícies de inundação. No litoral aparecem depósitos vinculados a pântanos e mangues, terraços marinhos, barras litorâneas, campos de dunas, praias e cordões litorâneos.

\section{Formações lateríticas}

Os lateritos na região amazônica desenvolveramse em dois períodos bem distintos: o Terciário Inferior (Eoceno-Oligoceno) e Terciário Superior/Pleistoceno (M.L. Costa 1991).

Os lateritos mais antigos, designados Lateritos Maturos (M.L. Costa 1991), constituem-se em perfis bem evoluídos, profundos. Têm no topo horizonte ferruginoso, ferro-aluminoso, bauxítico ou bauxíticofosfático, que abriga a maioria dos depósitos de bauxita da região. A crosta ferruginosa ou ferro-aluminosa comporta-se como proteção parcial contra a erosão física e intemperismo químico e na paisagem regional geralmente sustenta superfícies planas elevadas de platôs tendo dezenas a vários milhares de metros de extensão e altitudes de 50 a 800 m. Essas superfícies podem estar recobertas por latossolos e sedimentos ou até mesmo terem suas crostas expostas, e sobre elas desenvolveu-se floresta tropical ou paisagem de savana, respectivamente.

Essas crostas servem como referenciais na identificação de deslocamentos neotectônicos, manifestos em desníveis de platôs que podem ser observados em uma mesma área e entre áreas distintas. Nas regiões nordeste do Pará e noroeste do Maranhão observam-se morros, platôs e ilhas com formações lateríticas maturas, bauxíticas e bauxito-fosfáticas, em vários níveis topográficos, de 10 a $144 \mathrm{~m}$, mostrando que a neotectônica incidiu na região desnivelando a superfície laterítica delineada pelas crostas, antecedendo os perfis imaturos.

Os lateritos mais jovens, designados Lateritos Imaturos (M.L. Costa 1991), são de idade pós-Barreiras e pós-Solimões, e marcam-se por horizonte ferroalumino-argiloso. São pouco evoluídos, menos profundos e desprovidos de horizonte bauxítico ou bauxítico-fosfático. Delineiam, onde não se depositaram sedimentos quaternários, a paisagem de áreas topograficamente mais baixas dominantes na região amazônica.

Esses lateritos imaturos também sofreram deformações ligadas a manifestações neotectônicas, expressos na segmentação parcial ou total do perfil laterítico e rotação local dos segmentos.

A deformação dos lateritos indica que a neotectônica não atuou continuadamente na região amazônica, mas em pulsos, reconhecendo-se um primeiro que incidiu logo após a formação dos lateritos maturos, provavelmente no Mioceno, e um segundo, que sobreveio após a instalação dos lateritos imaturos, ainda no Pleistoceno. Adicionalmente, a deformação de stone lines derivadas de perfis imaturos serve como indicador de que a neotectônica se estendeu até os tempos recentes.

\section{ESTRUTURAS}

As estruturas neotectônicas da Região Amazônica passaram a ser melhor entendidas a partir de investigações de campo, acompanhadas de análise sistemática de cartas plani-altimétricas e de diversos produtos de sensores remotos, em diversas áreas-chave mostradas na Figura 1: (1) Nordeste de Roraima; (2) Centro-oeste do Amazonas; (3) Leste do Amazonas;(4) Oeste do Pará; (5) Centro-norte do Pará; (6) Leste do Amapá; (7) Nordeste do Pará; (8) Noroeste do Maranhão. (9) Sudeste do Pará e Oeste de Tocantins. (10) Nordeste de Tocantins/Sul do Maranhão. Algumas estruturas foram delineadas apenas com base na interpretação de anomalias, lineações e lineamentos de drenagem e de relevo, a exemplo do centro-oeste do Amazonas e do leste do Amapá.

A Figura 2 mostra a distribuição dos principais elementos estruturais do quadro neotectônico da região. Nessa figura, como nas que se seguem as falhas transcorrentes são indicadas por linhas com ou sem par de setas, estas apontando o movimento relativo; as falhas normais são indicadas por linhas com pequenos traços perpendiculares e as falhas inversas ou de cavalgamento são mostradas por linhas denteadas.

\section{Nordeste de Roraima}

A região nordeste de Roraima corresponde à porção mais setentrional do Brasil e inclui a área compreendida entre as cidades de Caracaraí, Boa Vista, Normandia e Pacaraima. $\mathrm{O}$ arcabouço neotectônico dessa área requer, para seu entendimento, que se considere também as informações disponíveis das regiões sudoeste da Guiana e sudeste da Venezuela, face à continuidade física das principais estruturas para esses países (Figura 3).

As primeiras referências a estruturas neotectônicas dessa área são devidas às investigações de Eiras \& Kinoshita (1988) que, a partir da interpretação de linhas sísmicas, demonstraram a existência de estruturas transpressivas afetando as seqüências mesozóicas que preenchem a Bacia do Tacutu. Essas estruturas são 


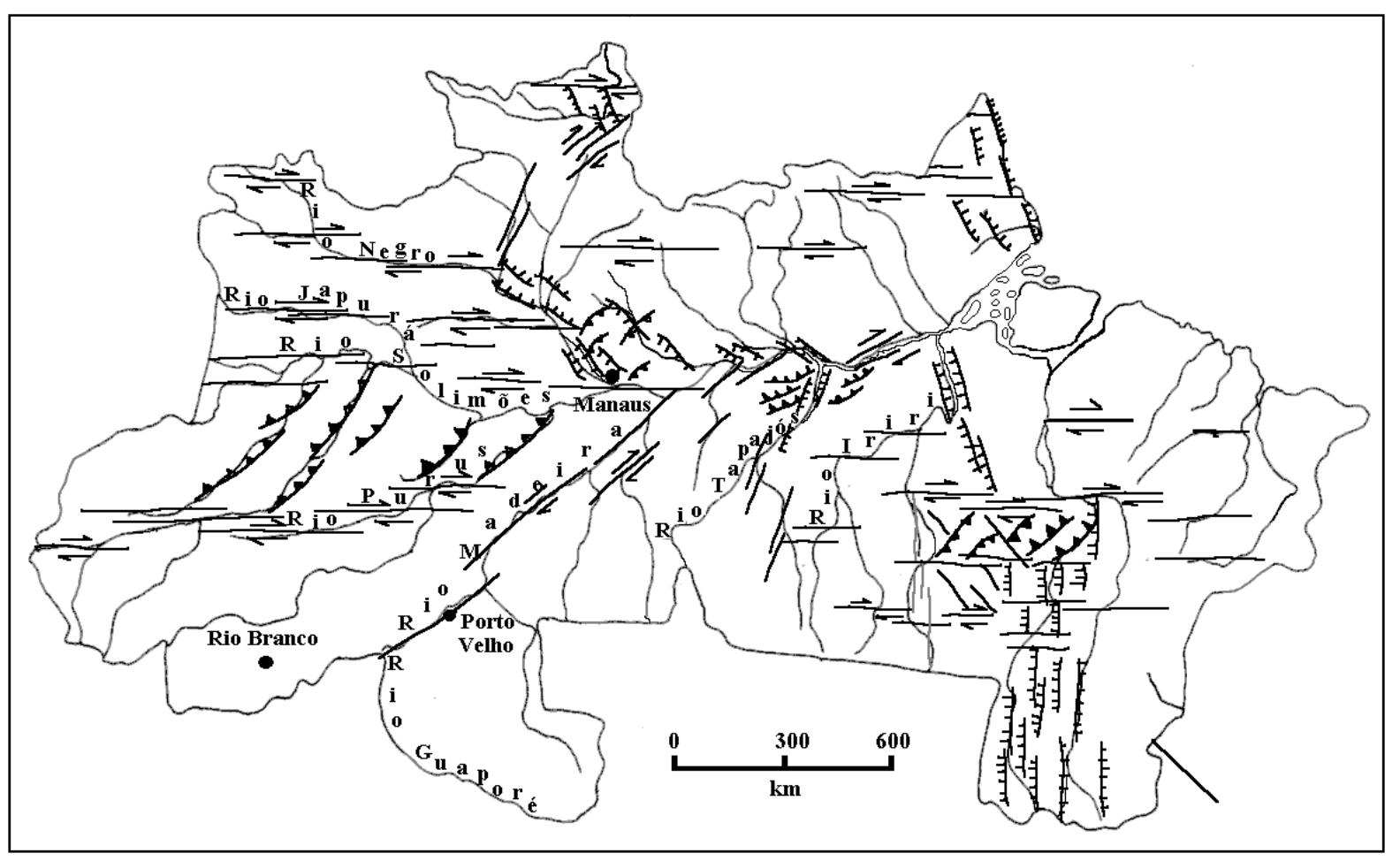

Figura 2: Arcabouço neotectônico da Região Amazonica, mostrando as falhas maiores.

Figure 2: Neotectonic framework of Amazonic Region, showing the major faults.

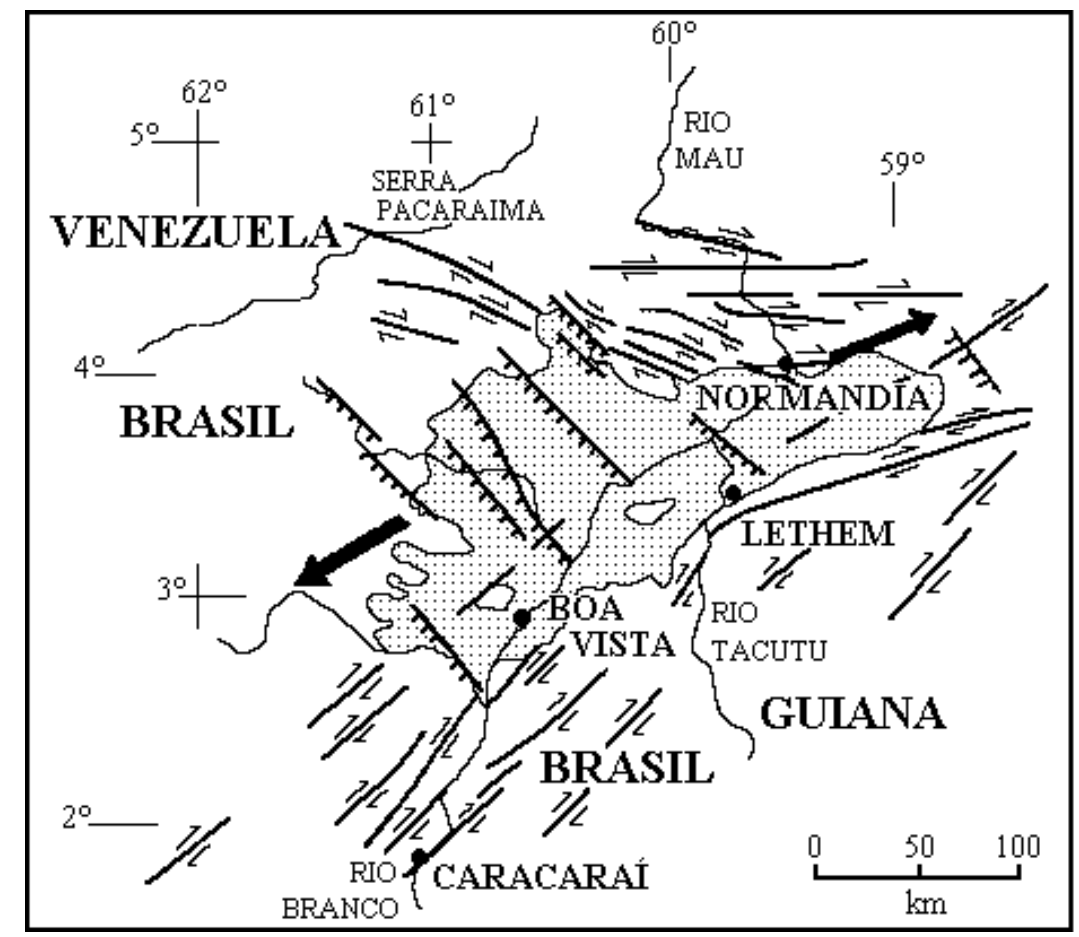

Figura 3: Estruturas neotectônicas maiores da região nordeste de Roraima e adjacências. Área pontilhada: Formações Boa Vista e Viruaquim. Em branco: unidades pré-cambrianas e mesozóicas. Flechas maiores: direção do eixo extensional $\sigma_{3}$.

Figure 3: Major neotectonic structures of northeast Roraima and adjacent areas. Stippled: Boa Vista and Viruaquim formations. White, precambrian and mesozoic units. Main arrows: direction of extensionl axis $\sigma_{3}$. 
dobras e falhas inversas que configuram flores positivas orientadas segundo NW-SE, relacionadas com falhas transcorrentes dextrais NE-SW. Esses autores consideraram também que estas falhas transcorrentes resultaram da reativação das falhas normais mesozóicas, a partir do Mioceno, induzida pelas colisões das placas Sul-Americana, do Caribe e de Nazca.

Novas informações foram adicionadas com investigações de campo realizadas por J.B.S. Costa \& J.A.V. Costa (1996), que definiram o quadro estrutural regional como uma bacia transtensiva em cunha, de direção geral ENE-WSW, formada por falhas normais NW-SE e por falhas transcorrentes dextrais E-W e NESW. Nela encontram-se depositados sedimentos da Formação Boa Vista.

A borda norte da bacia é delineada por numerosos feixes de falhas transcorrentes dextrais de direções E-W a WNW-ESE, que passam pelas regiões das cidades de Normandia e Pacaraima e se estendem para a Guiana e Venezuela. Nos afloramentos as falhas são identificadas através de faixas cataclásticas e duplexes simétricos e assimétricos de dimensões centimétricas a métricas, afetando rochas do Proterozóico Médio (graníticas da Suíte Saracura, vulcânicas do Grupo Surumu e sedimentares do Supergrupo Roraima). Em escala regional os diversos segmentos de falhas interagem através de falhas normais de direção NWSE e inclinadas para SW, caracterizando-se zonas transtensivas ao longo de toda a porção norte da bacia.

Tanto as falhas transcorrentes como as falhas normais expressam-se no relevo através de escarpas de falha e facetas trapezoidais, e controlam a orientação geral das serras, que alcançam altitudes de $1.000 \mathrm{~m}$ no sistema Pacaraima, e mais ao norte chegam a altitude de $2770 \mathrm{~m}$ no Monte Roraima na fronteira com a Venezuela. Em direção ao sul, nas adjacências do contato entre o embasamento e a Formação Boa Vista, as altitudes não ultrapassam $200 \mathrm{~m}$. Essa enorme variação de altitudes, de norte para sul, sugere que as falhas transcorrentes tiveram importante componente de rejeito de mergulho. Vales suspensos e lagos decorrentes de drenagens bloqueadas pelas falhas são comuns nessas áreas.

A borda sudeste da bacia é definida por várias falhas transcorrentes dextrais de direção NE-SW, ao longo das quais se desenvolveram áreas transpressivas caracterizadas pelos cavalgamentos e dobras de direções NW-SE reconhecidos por Eiras \& Kinoshita (1988). Considerando a orientação das estruturas transpressivas, pode-se deduzir que as falhas transcorrentes têm entre elas zonas de recobrimento lateral à esquerda. Tais estruturas afetam rochas précambrianas do Cinturão Granulítico Guiana Central e mesozóicas da Bacia do Tacutu, e se expressam no relevo através de serras alinhadas na direção NE-SW, com altitudes de até $500 \mathrm{~m}$. Vários segmentos dos rios Branco e Tacutu também são controlados pelas falhas transcorrentes. Como os sedimentos da Formação Boa Vista recobrem as estruturas transpressivas, pode ter ocorrido, provavelmente no Quaternário, um pulso transtensivo ao longo das transcorrências.

$\mathrm{O}$ interior da bacia marca-se como uma superfície relativamente plana com altitude em torno de $100 \mathrm{~m} \mathrm{e}$ contrasta com a morfologia da suas bordas $\mathrm{N}$ e SE. Esse pediplano é interrompido apenas pelas colinas alinhadas segundo NW-SE, que correspondem às partes externas dos blocos rotacionados por falhas normais, as quais controlaram também a deposição dos sedimentos da Formação Boa Vista. Essas falhas impuseram ainda forte controle em vários segmentos dos rios Viruaquim, Surumu, Parima, Uraricoera, Mucajaí e outros menores.

O desenvolvimento dessa bacia tem relação direta com a reativação de estruturas pré-cambrianas e mesozóicas. As falhas transcorrentes da borda norte projetaram-se ao longo de zonas de cisalhamento (cavalgamentos dúcteis) presentes nas unidades rochosas do Proterozóico Médio. As falhas transcorrentes da borda sudeste originaram-se através da reativação das zonas de cisalhamento do Cinturão Guiana Central e das falhas normais da Bacia do Tacutu.

Em termos de evolução da bacia, considera-se que ocorreram pelo menos dois episódios principais de movimentação. No Mioceno-Plioceno dominou subsidência na porção centro-norte e soerguimento na porção centro-sul. Tal situação parece ser comum em estruturas em forma de cunha geradas por sistemas transcorrentes dotados de mesmo sentido de movimentação (neste caso, dextral). Provavelmente no Quaternário a transpressão deu lugar a subsidência na porção centro-sul, propiciando a formação de novos depocentros e a extensão dos sedimentos Boa Vista para essa região. Esses dois momentos são bem definidos na evolução da estrutura e o eixo de distensão $\sigma_{3}$, orientado na direção ENE-WSW, operou continuamente desde o Mioceno.

\section{Centro-oeste do Amazonas}

A região centro-oeste do Amazonas inclui extensas áreas de ocorrência de seqüências sedimentares do Terciário Superior (Formação Solimões) e do Quaternário, além de áreas pré-cambrianas na porção do alto Rio Negro. Evidências de movimentos tectônicos positivos afetando as unidades cenozóicas, expressas por rios encaixados, migração de canais, terraços soerguidos e extensos segmentos de rios retilíneos, foram apontadas por Oliveira et al. (1977) e Franco e Moreira (1977) através de mapeamentos geomorfológicos.

Com base na análise do sistema de drenagem, reconhecem-se três compartimentos estruturais principais (Figura 4).

a) O compartimento sul é caracterizado por um padrão de drenagem paralelo formado por trechos dos rios Juruá e Purus, e seus afluentes, orientados preferencialmente na direção E-W. Ao longo dos elementos de drenagem, é comum a alternância regular de segmentos meandrantes ou retilíneos sugerindo a 


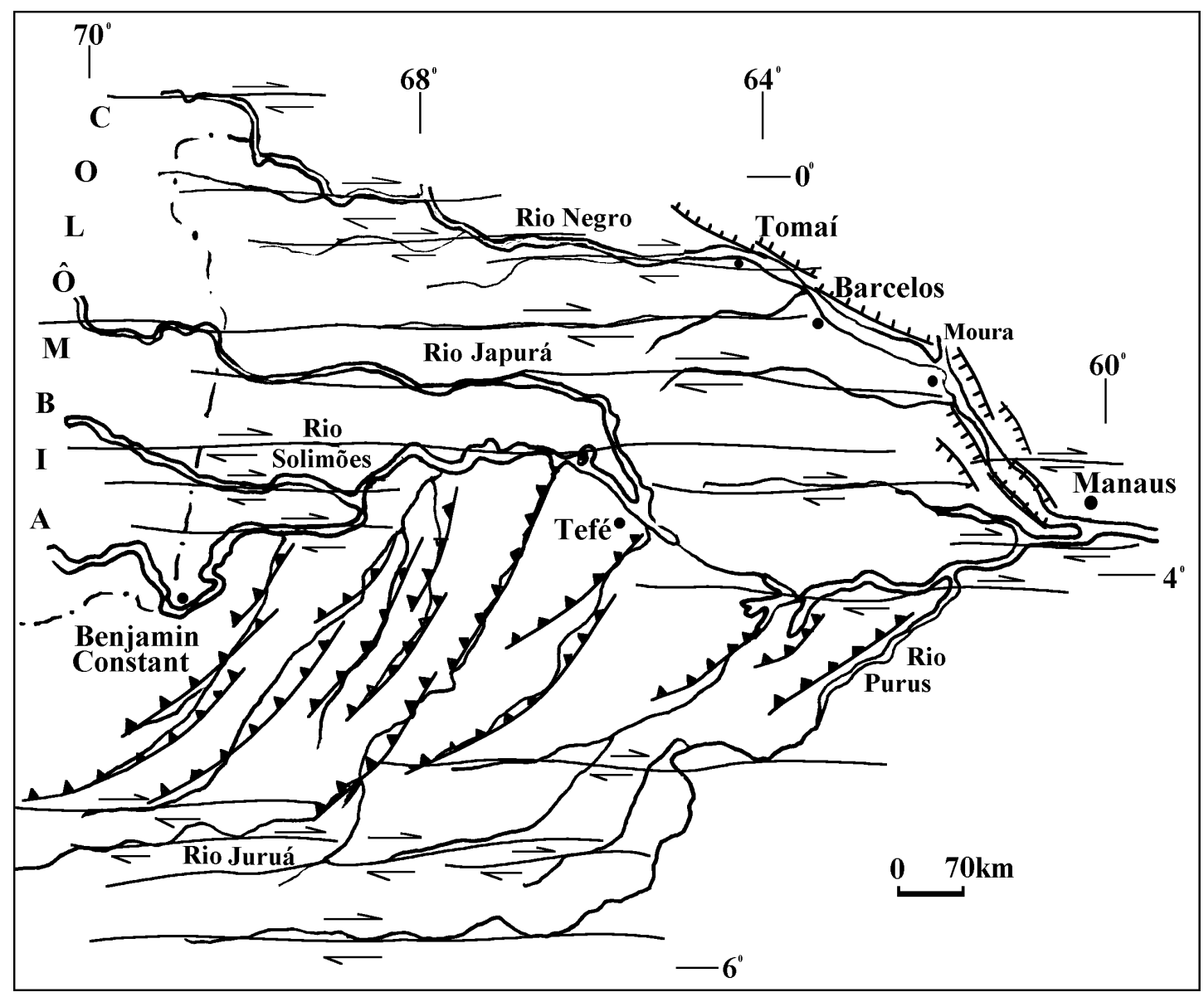

Figura 4: Estruturas neotectônicas maiores da região centro-oeste do Amazonas.

Figure 4: Major neotectonic structures of central-western region of Amazonas.

presença de áreas abatidas e soerguidas, respectivamente. Esse padrão indica que há pelo menos três feixes de lineamentos, que se estendem por mais de 700 km na direção E-W. Muitos desses lineamentos interligam-se através de outros menores orientados nas direções NE-SW e NNE-SSW, aos quais se relacionam anomalias em cotovelo na rede de drenagem. A presença de segmentos de drenagem deslocados indica movimentação dextral dominante nas falhas transcorrentes E-W e que os lineamentos menores devem representar falhas inversas.

b) O compartimento central compreende a área situada entre as cidades de Benjamim Constant e o baixo curso do Rio Purus. Também é caracterizado por um padrão de drenagem paralelo, controlado por vários feixes de lineamentos orientados nas direções NNESSW a NE-SW. O relevo apresenta faixas de áreas planas que se alternam com sistemas de colinas paralelas aos lineamentos, com altitudes em torno de $200 \mathrm{~m}$ e sustentadas pelos sedimentos da Formação Solimões. Esses lineamentos ligam-se às falhas transcorrentes do compartimento sul e são interpretados como falhas inversas. Não há dados suficientes para delinear as possíveis dobras associadas, mas grande parte do sistema de colinas alinhadas pode corresponder a essas estruturas. c) O compartimento norte estende-se desde a Colômbia até os baixos cursos dos rios Negro e Solimões. É definido por um padrão de drenagem retangular angulado e controlado principalmente por lineamentos de direções E-W e NE-SW. Paralelos aos lineamentos NE-SW aparecem também sistemas de colinas alinhadas e com altitudes de até $200 \mathrm{~m} \mathrm{e}$ esculpidas em sedimentos da Formação Solimões. Os lineamentos E-W são os mais importantes e muitos deles se interligam através dos lineamentos NE-SW. À semelhança do compartimento sul, esses lineamentos E-W são interpretados como falhas transcorrentes dextrais e os NE-SW, como falhas inversas, cujas articulações demarcam extensas estruturas romboédricas transpressivas.

Esses dados permitem que se descreva o arcabouço neotectônico dessa vasta área em termos de um segmento transpressivo (compartimento central) que se desenvolveu entre dois cinturões transcorrentes (compartimentos sul e norte) a partir de movimentação direcional dominantemente dextral.

No extremo nordeste dessa área, na região do baixo Rio Negro, a estruturação é definida principalmente por falhas normais de direção NW-SE interagindo com falhas maiores E-W, transcorrentes dextrais, resultando no desenvolvimento de várias bacias romboédricas 
transtensivas. A bacia mais importante situa-se na região de confluência dos rios Negro e Branco e aloja uma extensa seqüência sedimentar atribuída ao Quaternário. As falhas-mestras normais dessa bacia mergulham para nordeste e controlam a orientação geral do Rio Negro no alinhamento das cidades Moura e Barcelos.

\section{Leste do Amazonas}

Na região leste do Amazonas, sobretudo na área compreendida entre as cidades de Manaus e Juruti, existem dois conjuntos de estruturas decorrentes de movimentos do Terciário Superior e do Quaternário (J.B.S. Costa et al. 1994, 1995) (Figura 5) as possibilidades (1) de ter havido, em parte, acomodação interestratal durante a propagação das falhas, ou (2) de, alternativamente, esses segmentos representarem frações de dobras-em-caixa de dimensões quilométricas desenvolvidas no teto de cavalgamentos em rampas. Em vários afloramentos dentro da cidade de Manaus também são observados cavalgamentos com dobras associadas, destacando-se o perfil da Avenida Grande Circular onde os cavalgamentos têm geometria dominantemente em rampas.

As estruturas do Quaternário são representadas por duas bacias de afastamento (pull-apart) associadas a falhas transcorrentes dextrais de direções NE-SW e EW. No leste da área ocorrem as falhas NE-SW

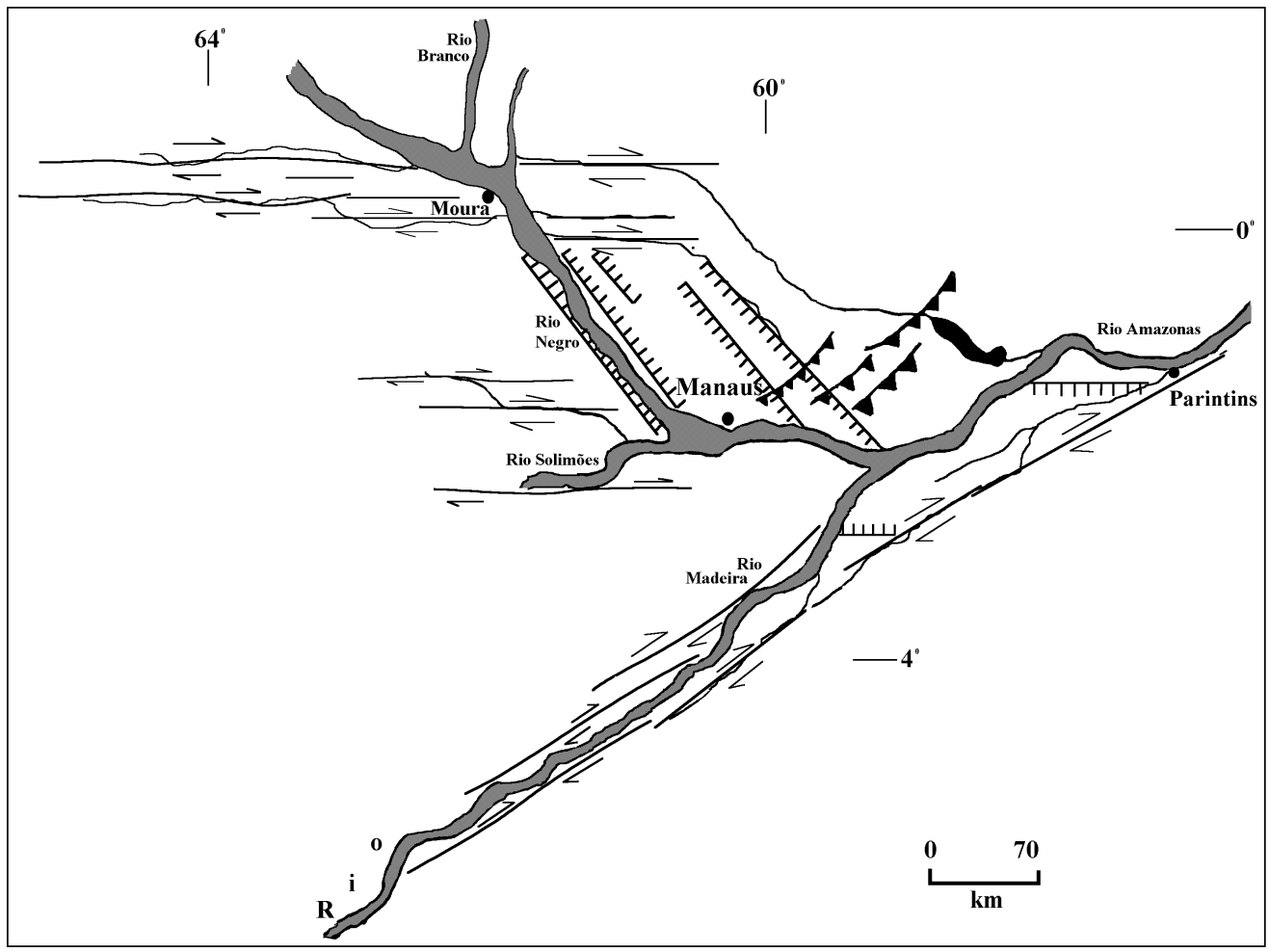

Figura 5: Estruturas neotectônicas maiores da região leste do Amazonas.

Figure 5: Major neotectonic structures of eastern region of Amazonas.

As estruturas mais antigas correspondem a falhas inversas e dobras orientadas na direção NE-SW, que afetam os sedimentos da Formação Alter do Chão e respondem pelo sistema de colinas delineando alinhamentos com altitudes de até $200 \mathrm{~m}$. Ao longo da rodovia AM-010, principalmente no trecho situado entre os rios Preto da Eva e Urubu, onde há boas exposições, as falhas inversas mergulham em torno de $40^{\circ}$ para SE e definem um sistema imbricado, aos quais se vinculam dobras abertas a suaves, de amplitudes e comprimentos de onda variando de alguns metros até dezenas de metros. Nessa área podem ser observados também extensos segmentos apresentando estratificação plano-paralela horizontal ou suavemente inclinada, indicando que os cavalgamentos concentraram-se em faixas discretas. Não se descartam compondo dois feixes que configuram um grande lineamento, o Lineamento Tupinambarana, e elas se ligam através de falhas normais de direção E-W; essas falhas formam um romboedro transtensivo, que acolhe extensos depósitos do Quaternário, controla o traçado do Rio Amazonas e encaixa o Rio Madeira. Na parte oeste dominam as falhas E-W conectadas através de falhas normais NW-SE, definindo outra bacia de afastamento. As falhas normais controlam a orientação dos Rios Preto da Eva e Urubu, e o baixo curso do Rio Negro, têm perfis planares e lístricos, e podem ser vistas principalmente dentro da cidade de Manaus e ao longo da Rodovia BR-174, onde se verifica que os rejeitos variam de poucos metros até dezenas de metros. Nessa área existem ainda falhas transcorrentes NE-SW afetando as falhas normais, sendo a mais importante 
aquela observada na Avenida Grande Circular, caracterizada por uma estrutura em flor negativa, que promove rotação de até $90^{\circ} \mathrm{em}$ alguns segmentos do perfil laterítico do Pleistoceno.

\section{Oeste do Pará}

Na região oeste do Pará as estruturas compõem dois conjuntos principais atribuídos ao Terciário Superior e ao Quaternário (J.B.S. Costa et al. 1994, 1995) (Figura $6)$. de canais devido a jogos de blocos de falha, bem como a ocorrência de extensos depósitos de sedimentos pelíticos vinculados principalmente às planícies de inundação.

b) O segmento distensivo NNE-SSW tem extensão em torno de $200 \mathrm{~km}$, é marcado por falhas normais que controlam o baixo curso do Rio Tapajós, e seu desenvolvimento deve ter relação com reativação das falhas normais do Mesozóico.

c) O segmento transcorrente tem direção ENE-WSW, estende-se desde Santarém até as adjacências de Gurupá

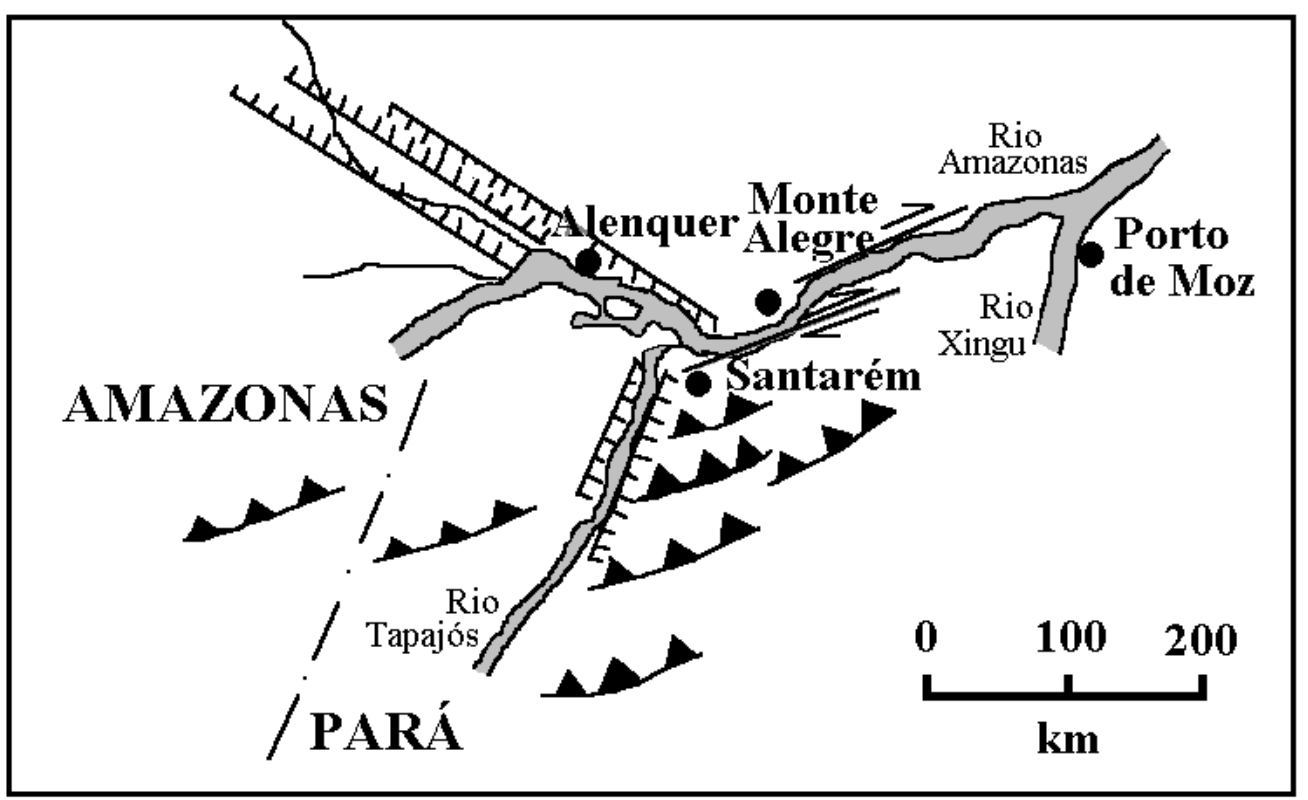

Figura 6: Estruturas neotectônicas maiores da região oeste do Pará. Figure 6:Major neotectonic structures of western region of Pará.

As estruturas do Terciário Superior, delineadas a partir das interpretações de linhas sísmicas (Travassos \& Barbosa Filho 1990), correspondem a falhas inversas e dobras de direções ENE-WSW e NE-SW que afetam os sedimentos da Formação Alter do Chão ao longo de uma faixa de $150 \mathrm{~km}$ de largura e $600 \mathrm{~km}$ de extensão. As falhas inversas formam sistemas imbricados mergulhando para NW (como mostra a Fig. 6) ou SE e marcam estruturas em flor positiva. As dobras têm dimensões quilométricas, apresentam estilos que variam de suaves a fechadas e possuem planos axiais verticais a subverticais. Essas estruturas se expressam no relevo através de sistemas de serras alongadas na direção NESW e com altitudes de até $200 \mathrm{~m}$.

As estruturas do Quaternário formam dois segmentos distensivos e um segmento transcorrente que se articulam na região de Santarém-Monte Alegre em uma junção tríplice do tipo R-R-T:

a) O segmento distensivo NW-SE tem extensão superior a $250 \mathrm{~km}$ e é formado por falhas normais de alto ângulo que controlam o baixo curso do Rio Trombetas e o trecho do Rio Amazonas entre as cidades de Juruti e Santarém. Ali é comum a presença de lagos relacionados com meandros abandonados por migração e impõe forte controle na orientação geral do Rio Amazonas. Esta porção é caracterizada também por extensos lagos resultantes principalmente de meandros abandonados por migração do Rio Amazonas para norte em resposta aos movimentos ao longo das falhas transcorrentes.

É oportuno ressaltar que na região do Município de Monte Alegre, que se situa na área de interação dos três segmentos, há registros de fontes termais e de incidência de terremotos sugerindo que as estruturas permanecem ativas. Além disso, reconhece-se ali uma grande anomalia magnética positiva (Hasui et al. 1984). Como feição algo mais antiga, identifica-se um enxame de diques básicos (Almeida 1986) que reflete um estágio mesozóico de evolução e marca provável pluma do manto, que pode ter promovido soerguimento e ruptura tríplice ancestral.

\section{Centro-norte do Pará}

A estruturação da região centro-norte do Pará também é definida por três segmentos estreitos e longos que se articulam na região do Município de Porto de Moz, e compõem uma junção tríplice do tipo T-T-R (Figura 7) atribuída ao Quaternário (J.B.S. Costa et al. 1994, 1995): 


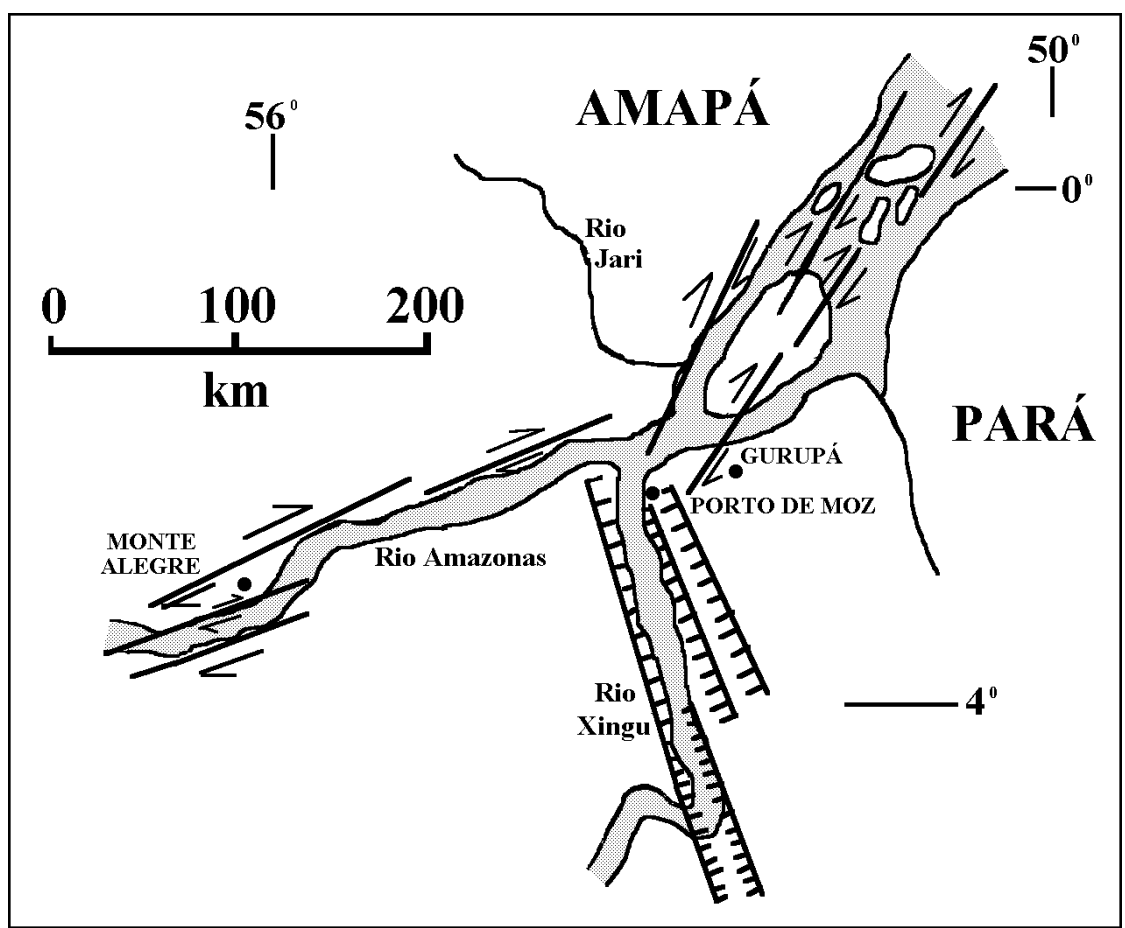

Figura 7: Estruturas neotectônicas maiores da região centro-norte do Pará. Figure 7: Major neotectonic structures of central-northern region of Pará.

a) O segmento distensivo tem extensão superior a $250 \mathrm{~km}$ na direção NNW-SSE, estende-se desde a região dos municípios de Altamira e Belo Monte até as adjacências da cidade de Porto de Moz. É marcado por falhas normais de alto ângulo que controlam o baixo curso do Rio Xingu; a continuidade desse segmento para sul é seguida através de extensos trechos retos de rios de segunda ordem orientados na direção NNWSSE.

b) O segmento direcional de direção NE-SW ocupa a área situada entre a cidade de Porto de Moz e a foz do Rio Amazonas, tem extensão de $350 \mathrm{~km}$ na região continental e é composto por vários feixes de falhas transcorrentes dextrais que se interligam através de falhas normais de direção ENE-WSW e E-W, definindo várias bacias de afastamento. A interpretação de linhas sísmicas no domínio da plataforma indica que as seqüências do Pleistoceno-Holoceno, acumuladas nos vários compartimentos transtensivos, podem alcançar espessuras da ordem de $1.000 \mathrm{~m}$, refletindo taxas elevadas de movimentação ao longo desse sistema transcorrente durante o Quaternário. De acordo com as interpretações baseadas em dados sísmicos e apresentados por Villegas (1994), essas falhas transcorrentes dextrais funcionaram ininterruptamente desde o Cretáceo, e sempre representaram o corredor de ligação entre o paleo-sistema de drenagem da região do Baixo Amazonas e o Oceano Atlântico. Essa interpretação está calcada na presença de sequiências do Terciário e do Cretáceo na Bacia de Mexiana com espessuras de $3 \mathrm{~km}$ e superiores a $6 \mathrm{~km}$, respectivamente. c) O outro ramo direcional da junção tríplice tem orientação ENE-WSW e já foi abordado no item anterior.

\section{Nordeste do Pará}

A região nordeste do Pará abrange a área situada entre o "Bico do Papagaio" (confluência entre os rios Araguaia e Tocantins ) e o litoral, incluindo a Ilha de Marajó, onde os dados estruturais respondem também por movimentos tectônicos do Terciário Superior e do Quaternário (J.B.S. Costa et al. 1993, 1994; Borges et al. 1995 a, b ) (Figuras 8 e 9).

O quadro de estruturas do Terciário Superior (Mioceno-Plioceno), mostrado na Figura 8, é formado por um compartimento transpressivo e outro transtensivo:

a) O compartimento transpressivo ocupa a área entre as cidades de Marabá e Paragominas, estende-se para a região oeste do Maranhão e tem a forma de um romboedro. Seus limites norte e sul correspondem a feixes de falhas transcorrentes E-W dextrais que afetam principalmente as seqüências sedimentares da Formação Ipixuna, atribuídas ao Terciário Inferior, bem como o perfil laterítico maturo, bauxítico-fosfático. $\mathrm{O}$ feixe norte (1) tem extensão aproximada de $560 \mathrm{~km}$ entre os vales dos rios Mearim e Tocantins, (2) responde pelas anomalias em cotovelo nas drenagens de terceira ordem, (3) exerce forte controle na orientação das drenagens de primeira e segunda ordens, e (4) inclui estruturas transpressivas e transtensivas ao longo de sua direção, a exemplo de estruturas em flor negativas observadas em cortes da BR-010 (Belém-Brasília). O 


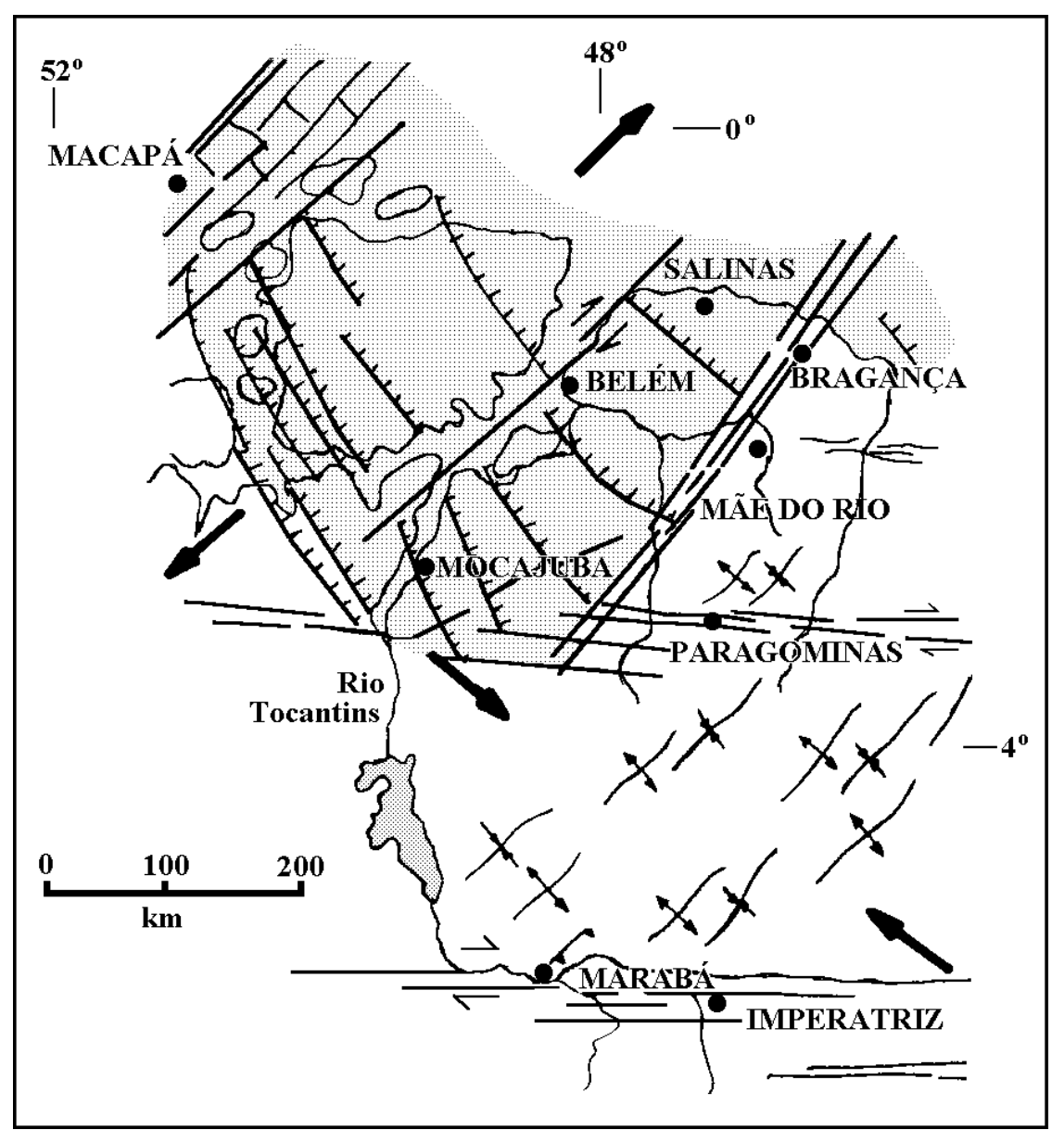

Figura 8: Estruturas maiores do Terciário Superior da região nordeste do Pará. Pontilhado: Sequiência Pirabas-Barreiras. Eixos de dobras: linhas com setas transversais convergentes em sinclinais ou divergentes em anticlinais. Flechas divergentes: orientação do eixo distensivo $\sigma_{3}$.

Flechas convergentes: orientação do eixo compressivo $\sigma_{r}$.

Figure 8:Major structures of Upper Terciary in the northestern region of Pará. Stippled: Pirabas-Barreiras sequence. Fold axis: lines with transverse spires, convergent in synclines or divergent in anticlines. Major divergent arrows: orientation of distensive axis $\sigma_{3}$.

Major convergent arrows: orientaton of compressive axis $\sigma_{l}$.

feixe sul (1) estende-se por mais de $350 \mathrm{~km}$ passando por Imperatriz e Marabá, (2) impõe anomalias em cotovelo no baixo curso dos rios Araguaia e Tocantins que configuram o "Bico do Papagaio", (3) controla o baixo curso do Rio Itacaiúnas, e (4) na região de Marabá tem suas principais falhas interagindo através de um pequeno segmento transpressivo. A parte interna desse compartimento é caracterizada por dobras de dimensões métricas a quilométricas e com eixos orientados na direção N40-70E, que se manifestam no relevo através de serras alinhadas e com altitudes de até $500 \mathrm{~m}$, as quais compõem a Serra do Tiracambu.

b) O compartimento transtensivo abarca a ilha de Marajó e o extremo nordeste do Pará, entre o município de Ipixuna e o litoral, e refere-se à bacia que alojou os sedimentos da Formação Pirabas e do Grupo Barreiras. As falhas-mestras normais que controlaram a instalação das seqüências sedimentares são observadas apenas em linhas sísmicas, orientam-se preferencialmente na direção NW-SE, mergulham para NE e têm perfis lístricos e planares; não é tarefa simples individualizar essas falhas no campo, pois elas foram reativadas também como falhas normais durante a evolução do Quaternário. Quanto ao desenvolvimento da bacia, J.B.S. Costa et al. (1995) e Borges et al. (1995a) sugeriram, com base em dados sedimentológicos, duas etapas principais: a primeira refere-se à individualização de falhas normais que propiciaram a ingressão do mar em uma extensa área, resultando na deposição da sequiência carbonática da Formação Pirabas, sobretudo nas partes nordeste e leste da bacia, e a segunda relaciona-se à progressão da movimentação ao longo das falhas normais e responde pela deposição da seqüência siliciclástica do Grupo Barreiras.

Essa bacia sempre foi interpretada como decorrente do último pulso extensional no continente do evento que gerou o Oceano Atlântico (Evento Sul-Atlantiano) (Igreja 1992; J.B.S. Costa et al. 1994, 1995), mas a análise integrada dos dados com os do compartimento transpressivo permite interpretá-la como uma estrutura 
de afastamento, cujo limite sul corresponde ao feixe de falhas transcorrentes que passa pela região de Paragominas. Assim sendo, o feixe de falhas transcorrentes NE-SW presente na região do baixo Amazonas pode ter tido papel importante no desenvolvimento do compartimento transtensivo, de modo a delinear uma estrutura em cunha semelhante à da região nordeste de Roraima. Outras falhas transcorrentes NE-SW funcionaram durante a evolução da bacia e aquela que passa em frente à cidade de Belém pode ter controlado a distribuição das seqüências sedimentares na direção NW-SE, pois não há registros de ocorrências expressivas de sedimentos carbonáticos da Formação Pirabas na região da Ilha de Marajó.

O quadro de estruturas do Quaternário (Pleistoceno Médio-Holoceno), mostrado na figura 9, compreende vários feixes de falhas transcorrentes dextrais E-W que se interligam através de falhas normais de direção NW$\mathrm{SE}, \mathrm{NNW}-\mathrm{SSE}$ e N-S, definindo várias estruturas romboédricas transtensivas (bacias de afastamento) de dimensões variadas. Essas estruturas afetam as seqüências sedimentares do Terciário Inferior (Formação Ipixuna) e do Terciário Superior (Formação Pirabas e Grupo Barreiras) e o perfil laterítico imaturo, que se constitui em boa referência para demonstrar que os rejeitos das falhas normais variam de poucos metros a várias dezenas de metros.

Os deslocamentos verticais ao longo das falhas normais respondem: (1) pela distribuição dos sedimentos da Formação Ipixuna e do Grupo Barreiras em faixas alternadas na região entre as cidades de Mãe do Rio e São Miguel do Guamá; (2) pelas exposições isoladas da seqüência carbonática da Formação Pirabas em meio aos sedimentos siliciclásticos do Grupo

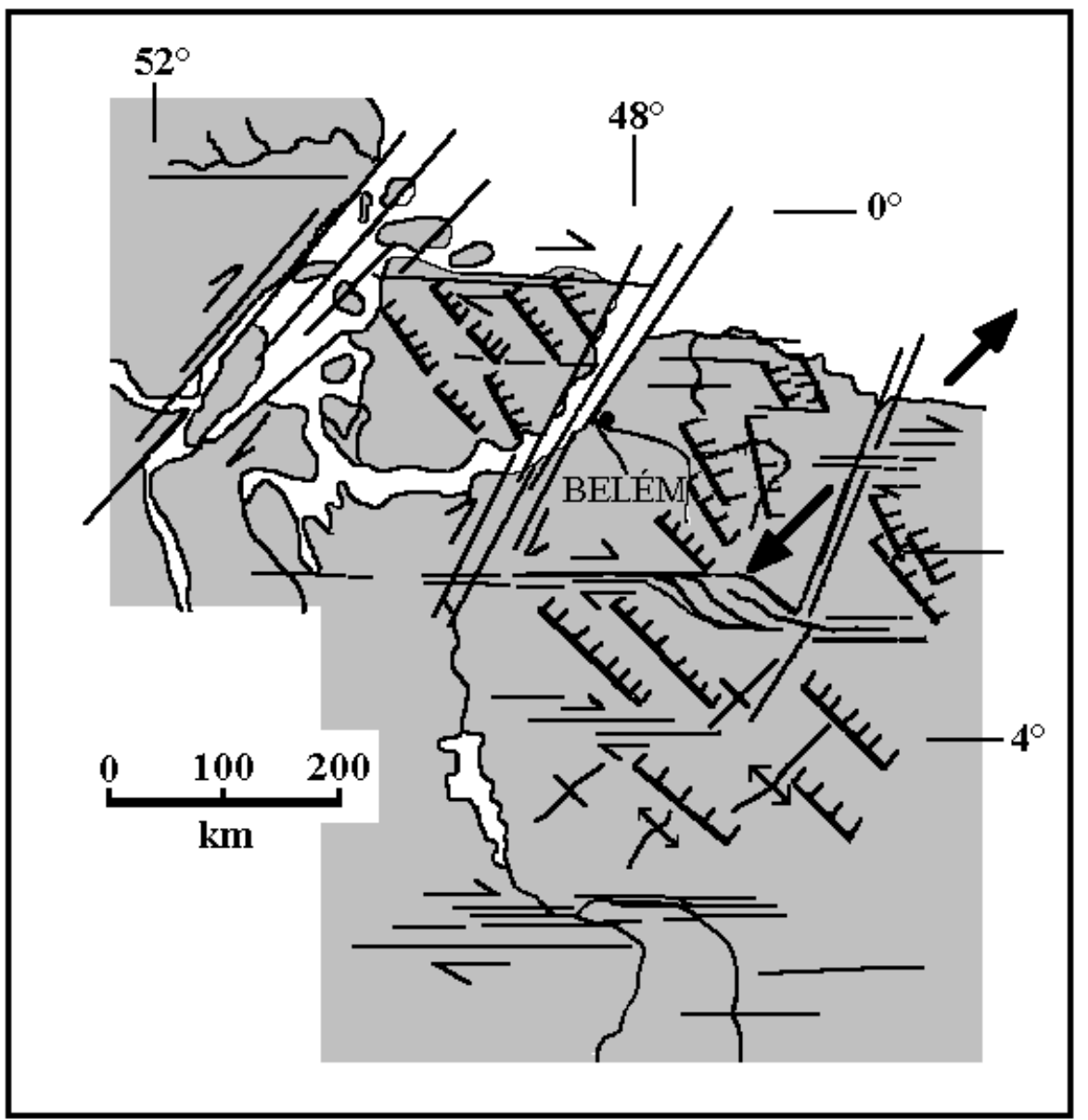

Figura 9: Estruturas maiores do Quaternário da região nordeste do Pará. Eixos de dobras: linhas com setas transversais convergentes em sinclinais ou divergentes em anticlinais.

Flechas divergentes: orientação do eixo distensivo $\sigma_{3}$.

Figure 9: Major quaternary structures in the northeastern region of Pará. Folds axis: lines with transverse arrows, convergent in synclines or divergent in anticlines.

Major divergent arrows: orientation of distensive axis $\sigma_{3}$. 
Barreiras, em decorrência de taxas altas de erosão das partes externas das capas soerguidas por rotação antihorária; (3) pelo basculamento da Ilha de Marajó promovendo migração de canais em direção à região sudoeste, onde domina um sistema de drenagem anastomosado; (4) pela deposição de grande parte das seqüências pleistocênico-holocênicas (Pós-Barreiras) de terraços fluviais, de depósitos de fluxos de detritos e de planícies costeiras; (5) pelo forte controle da dissecação do sistema colinoso; e (6) pelos arcos, cotovelos, segmentos retos, capturas e segmentos meandrantes nos elementos da rede de drenagem. $\mathrm{O}$ trecho do Rio Guamá entre Ourém e Belém é um bom exemplo de captura pelas falhas normais.

Os deslocamentos horizontais ao longo dos feixes transcorrentes geraram áreas transtensivas e transpressivas alternadas devido a mudanças nas direções das falhas ou interação entre elas. O exemplo que se destaca é o duplex transpressivo, de dimensões quilométricas, formado ao longo do feixe transcorrente que passa nas adjacências da cidade de Paragominas.

Vários feixes de falhas transcorrentes orientados na direção NE-SW seccionam algumas das estruturas apresentadas, constituem exemplos da última manifestação tectônica na região e estão intimamente ligados à reativação das falhas transcorrentes que operaram no Terciário Superior. Nesse quadro sobressaem-se os feixes que controlam (1) as disposições do baixo curso do Rio Tocantins e da Baía de Marajó, e (2) a orientação geral do Rio Gurupi, que juntamente com os feixes menores respondem, no geral, pela forma endentada do litoral, no caso caracterizada por rias.

\section{Noroeste do Maranhão}

A região noroeste do Maranhão entre os vales dos rios Gurupi e Mearim (Figura 10) possui também elementos estruturais originados por movimentos do Terciário Superior e do Quaternário (Ferreira Jr. 1996, Ferreira Jr. et al. 1996).

As estruturas do Terciário Superior restringem-se ao extremo nordeste da área e correspondem a falhas normais de direção NW-SE e inclinadas para NE, que limitam um depocentro preenchido por sedimentos do

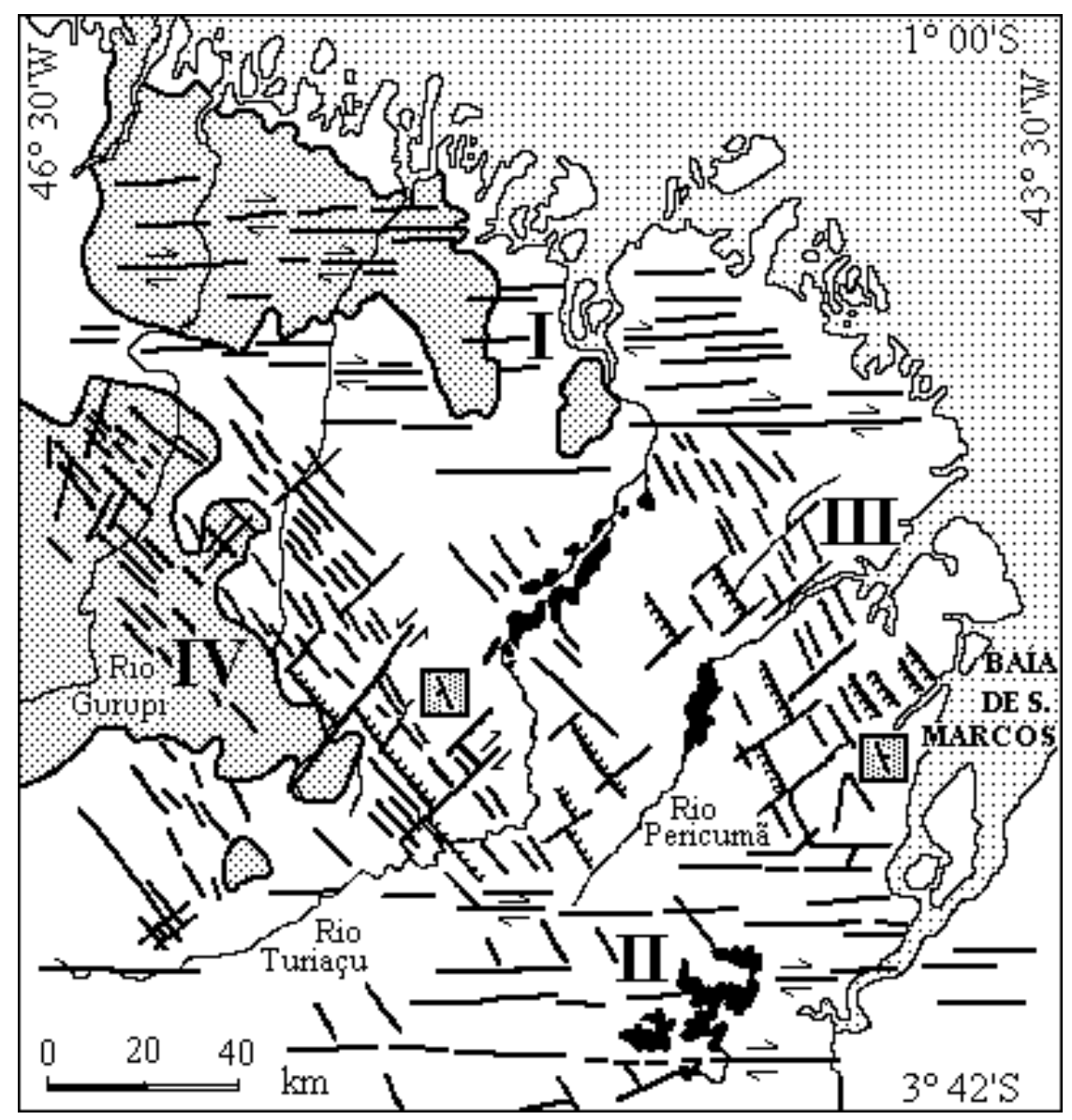

Figura 10: Estruturas neotectônicas maiores da região noroeste do Maranhão. Cruzes: unidades pré-cambrianas. I, II, III e IV: domínios morfoestruturais.

Atitude geral do acamamento: pequeno traço com um dente.

Figure 10: Major neotectonic structures of northwestern region of Maranhão. Crosses: precambrian units I, II, III and IV: morphostructural compartments. Bedding: small line with denticle. 
Grupo Barreiras. A interpretação dos dados sedimentológicos indica que os desnivelamentos induzidos pelos movimentos verticais propiciaram a instalação das seguintes seqüências, do interior do continente em direção ao paleolitoral: (1) seqüência de leques aluviais caracterizados por conglomerados e arenitos conglomeráticos na porção proximal e arenitos maciços de granulometria fina na porção distal; (2) sequiência ligada a sistemas fluviais meandrantes e a extensas planícies de inundação; e (3) seqüência transicional dominada por marés de baixa energia. Trata-se de uma bacia assimétrica, cujo limite SW corresponde a áreas elevadas, alongadas na direção NW-SE e sustentadas principalmente por sedimentos do Cretáceo (Formação Itapecuru), marcando a zona de ombreira.

Nessa época, a paleolinha de costa situava-se nas adjacências da cidade de Mirinzal e já possuía configuração trombetiforme definida por rias controladas por falhas transcorrentes de direção NESW. Na progressão da movimentação houve o recuo da linha de costa e a gradual ampliação da rede de drenagem dominada por elementos hidrográficos orientados preferencialmente na direção NE-SW.

A estruturação do Quaternário refere-se a uma bacia de tipo de afastamento com as bordas norte e sul marcadas por falhas transcorrentes dextrais E-W e as nordeste e sudoeste, marcadas por falhas normais NWSE:

a) As falhas transcorrentes do limite norte (domínio I) têm extensão superior a $150 \mathrm{~km}$ na direção E-W e se expressam nos afloramentos como duplexes de dimensões centimétricas a métricas afetando os sedimentos da Formação Itapecuru e do Grupo Barreiras. Esta geometria repete-se regionalmente, com domínio de duplexes transtensivos constituídos por falhas normais NW-SE que ligam as falhas transcorrentes. Nessa região o relevo é composto por colinas médias, colinas amplas e colinas médias alongadas na direção $\mathrm{E}-\mathrm{W}$ e com altitudes variando entre 35 e $70 \mathrm{~m}$, e o padrão de drenagem dominante é o paralelo, sendo fortemente controlado pelas falhas transcorrentes.

b) As falhas transcorrentes do limite sul (domínio II) compõem um feixe que se prolonga para a região nordeste do Pará com extensão superior a $300 \mathrm{~km}$, apresentam estruturas romboédricas transtensivas ao longo de suas direções e impõem traçados paralelos na rede de drenagem. Os lagos existentes nas regiões dos municípios de Monção, Penalva e Viana resultaram de bloqueios da rede de drenagem devido à individualização das estruturas romboédricas ao longo das falhas. Dentre as formas de relevo dessa região destacam-se as mesas que formam interflúvios tabulares com altitudes em torno de $110 \mathrm{~m}$, bordas escarpadas e topos chatos, e são sustentadas pela crosta laterítica desenvolvida sobre sedimentos da Formação Itapecuru.

c) As falhas normais do lado nordeste (domínio III) apresentam mergulhos variando de $75^{\circ}$ a $50^{\circ}$ para $\mathrm{SW}$, possuem rejeitos de poucos metros até dezenas de metros, têm perfis planares e lístricos, contêm estrias inclinadas entre $40^{\circ}$ e $70^{\circ}$ para $\mathrm{NW}$ e definem um sistema imbricado em dominó. Essas falhas bloquearam parte do sistema de drenagem formando os lagos dos municípios de Pinheiro e Santa Helena, e controlaram os sistemas de colinas amplas, colinas médias, e colinas médias alongadas caracterizadas por forte assimetria.

d) As falhas normais do lado sudoeste (domínio IV) têm perfis planares, possuem mergulhos médios a altos para NE, formam um sistema imbricado em dominó e controlam as formas de relevo em colinas médias alinhadas, paralelas e fortemente assimétricas. Face à menor expressão topográfica, considera-se que os rejeitos dessas falhas são inferiores aos registrados naquelas do lado nordeste.

O desenvolvimento dessa bacia é entendido através de quatro etapas:

a) A primeira corresponde à individualização das falhas transcorrentes E-W que impuseram modificações importantes na rede de drenagem, sobretudo por capturas de segmentos de rios, que tiveram suas direções mudadas de NE-SW para E-W, e por bloqueios de drenagem que formaram os lagos da parte sul.

b) A segunda refere-se à formação das falhas normais dos lados NE e SW da bacia, resultando no desenvolvimento dos sistemas de colinas, na geração dos lagos da parte central e na instalação da sequiência holocênica.

c) A terceira diz respeito à ingressão do mar no interior da bacia originando os depósitos de planície de lama.

d) A quarta relaciona-se com individualização das falhas transcorrentes NE-SW, destacando-se aquela que controla a baía de São Marcos.

\section{Leste do Amapá}

O quadro de estruturas das regiões leste do Amapá (Figura 11) é similar ao apresentado para as regiões nordeste do Pará e noroeste do Maranhão.

As estruturas do Terciário Superior são falhas normais orientadas na direção NNW-SSE e inclinadas para ENE. Elas formam parte da arquitetura de uma bacia assimétrica preenchida por sedimentos do Grupo Barreiras e são fortemente controladas por falhas normais mesozóicas da Bacia do Cassiporé. Não há ainda informações disponíveis para avançar no entendimento da evolução dessa bacia, mas a julgar pelas informações das demais regiões litorâneas admitese que se trata também de uma estrutura transtensiva.

As estruturas do Quaternário compreendem vários feixes de falhas transcorrentes E-W que se interligam através de falhas normais NW-SE, definindo romboedros transtensivos simétricos e assimétricos, de dimensões variadas. Essas estruturas têm continuidade para os países vizinhos (Guiana Francesa, Suriname e Guiana), estendem-se por mais de $600 \mathrm{~km}$ na direção $\mathrm{E}-\mathrm{W}$ e controlam a forma do litoral. Os movimentos verticais transtensivos (1) geraram bloqueios no sistema de drenagem formando lagos (Motuca, Novo, 


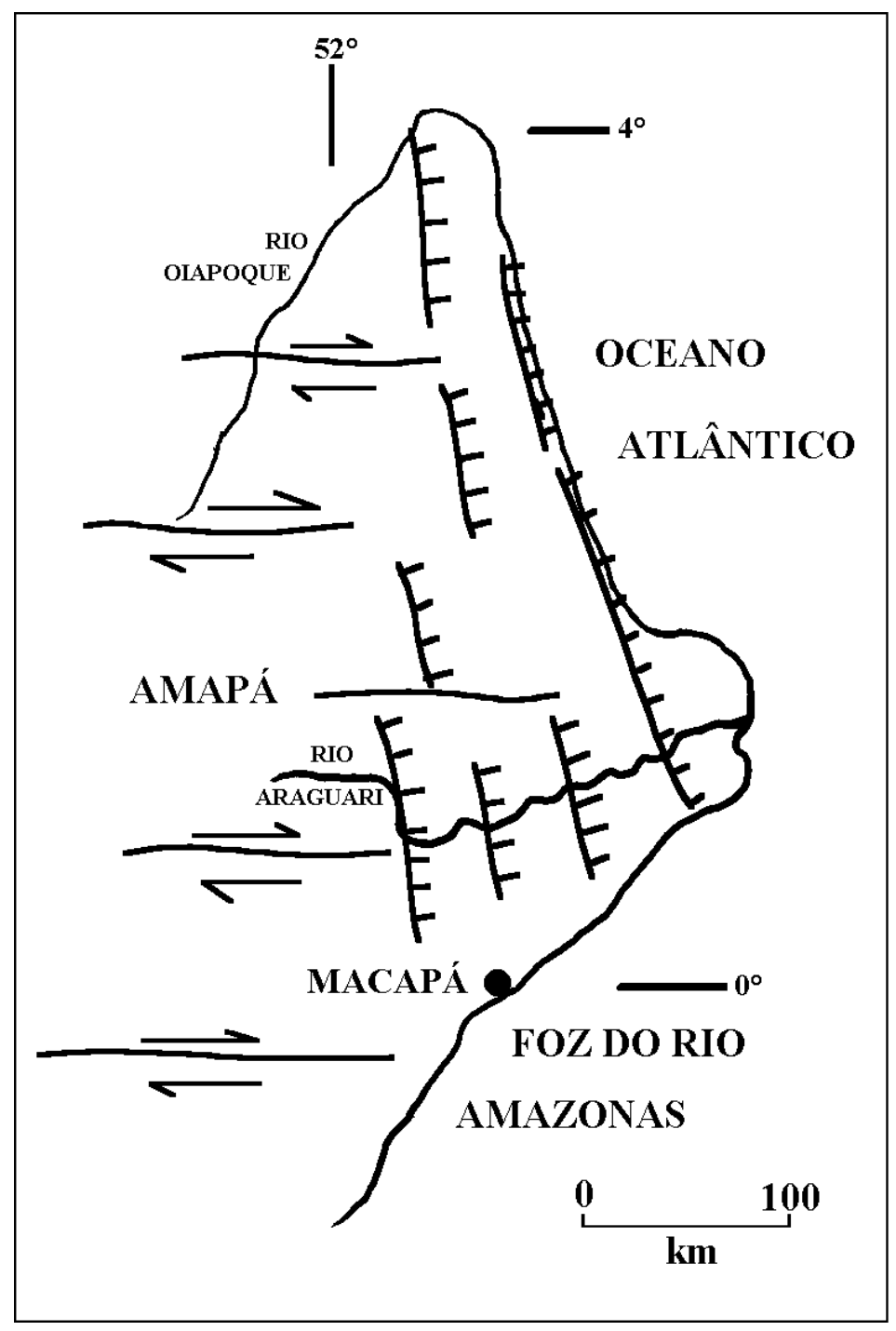

Figura 11: Estruturas neotectônicas das regiões leste do Amapá. Figure 11: Neotectonic structures of the eastern regions of Amapá.

Comprido, Duas Bocas etc.) e segmentos sinuosos nos elementos de drenagem de terceira ordem (por exemplo, Rio Araguari); e (2) envolveram rotação anti-horária nos blocos falhados, resultando em migração do sistema de drenagem para SW e conseqüente formação de numerosos paleocanais, sobretudo na região compreendida entre as cidades de Amapá e Sucuriju.

\section{Sudeste do Pará e oeste de Tocantins}

As principais estruturas neotectônicas da região sudeste do Pará e oeste de Tocantins são representadas por três feixes de falhas transcorrentes E-W e dois feixes de falhas normais N-S (Figura 12):

O feixe transcorrente que passa no extremo norte dessa área (1) tem extensão superior a 500 km, (2) prolonga-se para leste em direção à parte norte do Estado do Tocantins, (3) controla os baixos cursos dos rios Itacaiúnas e Parauapebas, e o alto curso do Rio Bacajá, (4) gera anomalias em cotovelo no traçado dos rios Xingu, Araguaia e Tocantins definindo, nos dois últimos o "Bico do Papagaio", e (5) constitui o limite norte da Serra dos Carajás. Essas falhas afetam rochas pré-cambrianas, seqüências sedimentares do Paleozóico e do Terciário Inferior, bem como o perfil laterítico maturo.

O feixe transcorrente situado na porção central encontra-se entre os vales dos rios Xingu e Araguaia, tem extensão aproximada de $370 \mathrm{~km}$, responde por várias anomalias da rede de drenagem (segmentos retos, cotovelos, sinuosidades etc.) e afeta principalmente as rochas pré-cambrianas.

Esses dois feixes transcorrentes, norte e central, interligam-se através de descontinuidades orientadas na direção NE-SW, que controlam a orientação de extensos segmentos dos rios Itacaiúnas, Parauapebas e Vermelho, e são interpretados como falhas inversas decorrentes da movimentação dextral. Grande parte da expressão topográfica dessa região, representada por um sistema de serras de até 800 m (Serra dos Carajás), 


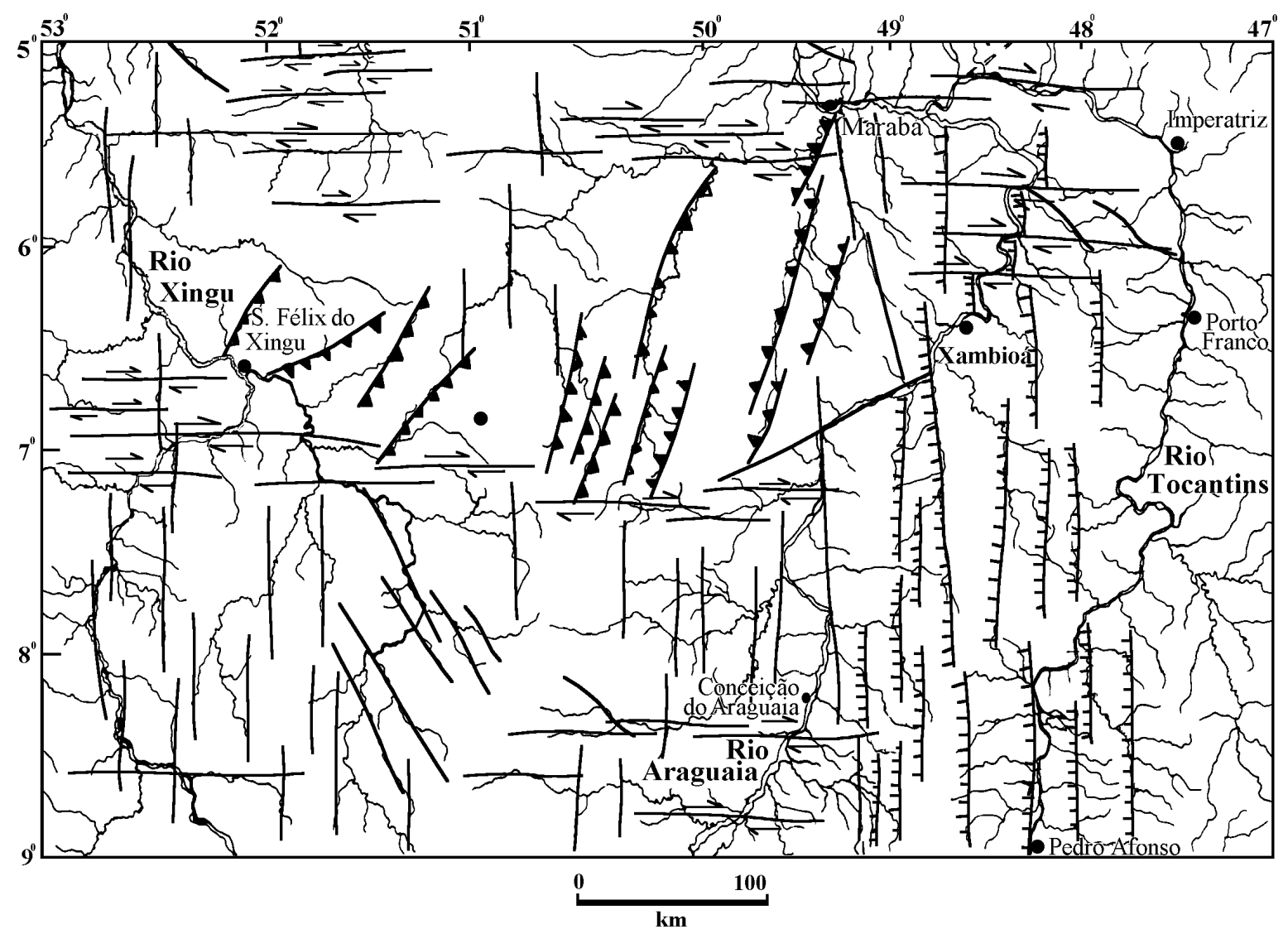

Figura 12: Estruturas neotectônicas maiores da região sudeste do Pará e oeste de Tocantins.

Figure 12: Major neotectonic structures of southeastern region of Pará and western region of Tocantins.

está vinculada aos movimentos verticais associados a transpressão; estima-se que os rejeitos ao longo das falhas inversas podem ter alcançado várias centenas de metros, exumando um paleo-relevo fortemente condicionado pelas estruturas pré-cambrianas subverticais. Os sistemas de serras com topos planos são capeados pela crosta laterítica matura, a exemplo do que se verifica na área transpressiva da Serra de Tiracambu na parte oeste do Maranhão. Os eventos de sismicidade registrados recentemente na área do prospecto Salobo e as fontes termais na região de Cururu são evidências de que as falhas da região da Serra dos Carajás permanecem ativas.

O feixe transcorrente do sul da área tem extensão aproximada de $200 \mathrm{~km}$, controla a orientação geral do Rio Inajá e o alto curso do Rio Arraias do Araguaia, e se conecta ao feixe transcorrente central através de um conjunto de falhas normais de direção NW-SE, definindo uma estrutura transtensiva.

Os feixes de falhas normais N-S concentram-se nos extremos leste e oeste da área. O feixe do lado oeste é realçado por extensos trechos retilíneos dos rios Xingu e Fresco, bem como pela orientação geral das drenagens de primeira e segunda ordens, e estende-se por mais de $1.000 \mathrm{~km}$ para norte e para sul, além dos limites da área enfocada. $\mathrm{O}$ feixe do lado leste compreende falhas normais fortemente inclinadas para oeste, as quais são destacadas por extensos trechos retilíneos do Rio Araguaia e de seus principais afluentes; os movimentos verticais associados respondem pelo conjunto de serras alinhadas na direção N-S (Serra do Estrondo) que compõem o divisor das bacias hidrográficas dos rios Araguaia e Tocantins.

\section{Nordeste do Tocantins e sul do Maranhão}

Nas regiões nordeste de Tocantins e sul do Maranhão (Figura 13), as estruturas neotectônicas compõem extensas faixas de direção E-W e N-S reunidas por Bezerra \& J.B.S. Costa (1996), no Cinturão Transcorrente Tianguá-Carolina e no Cinturão Distensivo Tocantins-Araguaia, respectivamente.

O Cinturão Transcorrente Tianguá-Carolina achase desenvolvido principalmente sobre seqüências sedimentares paleozóicas e mesozóicas pertencentes à Bacia do Parnaíba e é composto por falhas transcorrentes dextrais de direção ENE-WSW, que se interligam através de falhas normais orientadas segundo NW-SE, definindo várias áreas transtensivas, além de falhas transcorrentes dextrais e sinistrais de direção NE-SW. As estruturas-mestras do cinturão são as falhas transcorrentes ENE-WSW, que se concentram em faixas discretas, e as extensas áreas transtensivas. Para fins de descrição foram distinguidos os sistemas transcorrentes Rio Feio, Mosquito-Curicaca, CarolinaPedra Caída, Alto Arraias-Itapecuru, e as zonas transtensivas Campo Alegre-Rio Farinha e Alto Itapecuru-Carolina (Bezerra \& J.B.S. Costa 1996): 


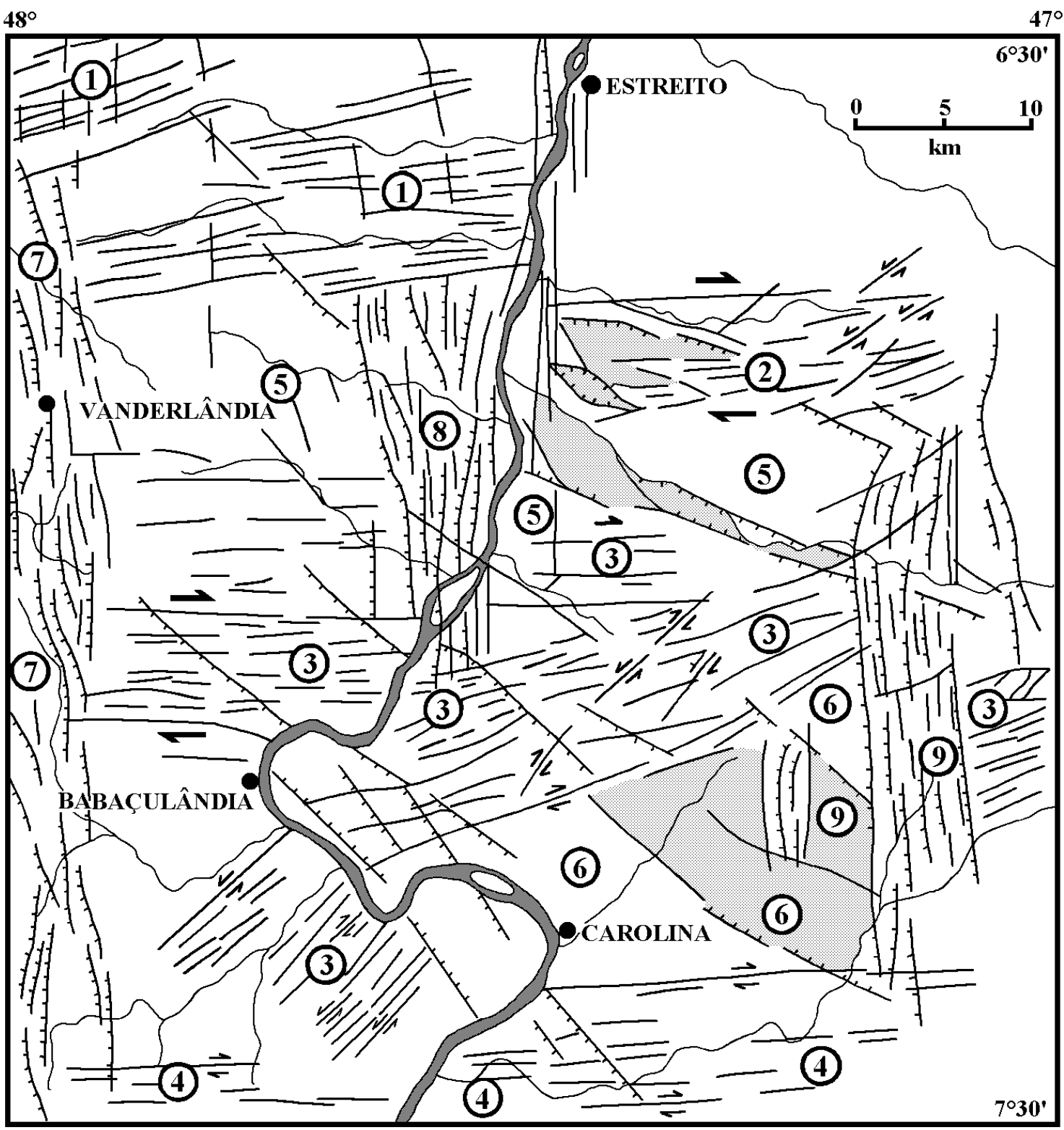

Figura 13: Estruturas neotectônicas maiores das regiões nordeste de Tocantins e sul do Maranhão. Pontilhado: rombográbens. Cinturão Tianguá-Carolina: (1) Sistema Transcorrente Mosquito-Curicaca, (2) Sistema Transcorrente Rio Feio, (3) Sistema Transcorrente Carolina-Pedra Caída, (4) Sistema Transcorrente Alto

Arraias-Itapecuru, (5) Sistema Transtensivo Campo Alegre-Rio Farinha, (6) Sistema Transtensivo Alto Itapecuru-Carolina. Cinturão Tocantins-Araguaia: (7) Sistema distensivo Vanderlândia, (8) Sistema distensivo Estreito-São José, (9) Sistema distensivo Itaueiras-Rejeitado.

Figure 13: Major neotectonic structures of the northeastern regions of Tocantins and southern region of Maranhão. Stippled: rhombograbens. Tinguá-Carolina Belt: (1) Mosquito-Curicaca Transcurrent System, (2) Rio Feio Transcurrent System, (3) Carolina-Pedra Caída Transcurrent System, (4) Alto Arraias-Itapecuru Transcurrent System, (5) Campo Alegre-Rio Farinha Transtensile System,, (6) Alto Itapecuru-Carolina Transtensile System. Tocantins-Araguaia Belt: (7) Vanderlândia Distensional System, (8) Estreito-São José Distensional System, (9) Itaueiras-Rejeitado Distensional System.

a) O sistema transcorrente Mosquito-Curicaca ocupa a parte noroeste da área, estende-se por aproximadamente $25 \mathrm{~km}$ entre os sistemas distensivos Vanderlândia e Estreito-São José, e condiciona a orientação geral dos elementos principais da rede hidrográfica e do relevo. As anomalias de drenagem expressam-se através de segmentos meandrantes alternados com segmentos retos nos cursos dos rios Mosquito e Curicaca, indicando a existência de pequenas áreas abatidas ao longo das falhas transcorrentes e interpretadas como bacias transtensivas. Esse quadro reflete-se no relevo através de serras alinhadas e com altitudes de até $300 \mathrm{~m}$ separadas por áreas de gradiente morfológico menos expressivo na direção E-W. 
b) O sistema transcorrente Rio Feio situa-se no quadrante nordeste da área, tem extensão aproximada de $20 \mathrm{~km}$ e é limitado a leste e a oeste, respectivamente, pelos sistemas distensivos Estreito-São José e ItaueirasRejeitado. Controla toda a extensão do vale do Rio Feio na direção E-W e afeta as seqüências das formações Sambaíba e Mosquito. Na extremidade oeste as falhas transcorrentes têm um arranjo anastomosado delineando cordões de sigmóides e romboedros transtensivos ao longo de uma extensão em torno de 7 $\mathrm{km}$ na direção E-W. Na extremidade leste existem várias falhas transcorrentes sinistrais de direção NESW interagindo com as transcorrências-mestras e isolando estruturas em cunha; como não há ocorrências de depósitos recentes nessa porção da área, pode ter dominado movimentação transpressiva nos feixes de estruturas em cunha.

c) O sistema transcorrente Carolina-Pedra Caída ocorre na parte central da área, define uma faixa com largura superior a $10 \mathrm{~km}$, é limitado a oeste pelo sistema distensivo Vanderlândia e acha-se segmentado na região leste pelo sistema distensivo Itaueiras-Rejeitado. As falhas-mestras transcorrentes dextrais ENE-WSW e as falhas transcorrentes dextrais e sinistrais de direção NE-SW respondem (1) pelo padrão retangular dominante na rede de drenagem (2) pelas anomalias em cotovelo no trecho do Rio Tocantins entre as cidades de Carolina e Babaçulândia, e (3) pela orientação preferencial dos elementos do relevo, sobretudo as "Mesas de Carolina". As articulações entre as falhas mestras e secundárias geram duplexes romboédricos com dimensões variando de poucos metros até alguns quilômetros na parte central do sistema. Existem também estruturas sigmoidais e romboédricas ao longo das falhas-mestras que podem ser seguidas em todas as escalas de observação.

d) O sistema transcorrente Alto Arraias-Itapecuru estende-se ao longo do limite sul da área por mais de $45 \mathrm{~km}$, é limitado a oeste pelo sistema distensivo Vanderlândia e controla os baixos cursos dos rios Itapecuru e Manoel Alves Grande. As informações de campo ainda são poucas nessa área, mas a presença de segmentos sinuosos alternados com segmentos retos de drenagem de terceira ordem, sobretudo ao longo do Rio Itapecuru, sugere a existência de áreas soerguidas e abatidas na direção geral do sistema; nesse quadro destacam-se as estruturas transtensivas a sul de Carolina definidas por falhas normais de direção N40-60W que ligam as falhas transcorrentes.

e) A zona transtensiva Campo Alegre-Rio Farinha encontra-se desenvolvida entre os sistemas transcorrentes Mosquito-Curicaca e Rio Feio e o sistema transcorrente Carolina-Pedra Caída, e é caracterizada por falhas normais orientadas na direção NW-SE. Tratase de uma bacia de afastamento simétrica e alongada na direção NW-SE, onde se instalaram seqüências siliciclásticas (Unidade Rio Farinha) decorrentes de erosão das áreas elevadas adjacentes e limitadas pelas falhas normais. Destaca-se ainda que todo o baixo curso do rio Farinha é controlado pelas falhas normais, correspondendo a um elemento axial da rede de drenagem na bacia de afastamento.

f) A zona transtensiva Alto Itapecuru-Carolina situase entre os sistemas transcorrentes Alto ArraiasItapecuru e Carolina-Pedra Caída, corresponde também a uma bacia de afastamento simétrica e limitada por falhas normais NW-SE, e aloja depósitos arenosos cuja natureza ainda não foi investigada.

O Cinturão Distensivo Tocantins-Araguaia é formado por falhas normais de direção N-S que se concentram em três faixas denominadas sistemas distensivos Vanderlândia, Estreito-São José e ItaueirasRejeitado (Bezerra \& J.B.S. Costa 1996), que controlam a orientação geral dos rios Tocantins e Araguaia imediatamente a oeste do limite da área. O sistema Vanderlândia mergulha para oeste e os outros dois acham-se preferencialmente inclinados para leste, e seus rejeitos respondem pelo conjunto de elevações da Serra do Estrondo e pelo deslocamento dextral dos sistemas transcorrentes, nesse caso implicando distensão oblíqua. O desenvolvimento desses sistemas resultou da reativação das falhas normais do Cretáceo durante a atuação dos movimentos transcorrentes dextrais no Terciário Superior e no Quaternário.

\section{SISMICIDADE NA AMAZÔNIA}

Os sismos em domínios intraplaca, como o caso da região amazônica, representam alívios de tensão ao longo de descontinuidades preexistentes reativadas ou menos provavelmente neoformadas, indicando, pois, movimentação tectônica atual.

Um cadastro de dados sismológicos foi apresentado por Berrocal et al. (1984) e atualizado por Mioto (1993). A distribuição dos epicentros da região mostra concentrações em áreas limitadas, que correspondem a zonas sismogênicas, separadas por vastas extensões onde apenas alguns epicentros aparecem esparsamente representando alívios locais de tensão. As zonas sismogênicas foram relacionadas com zonas de fraqueza crustal (Hasui et al. 1993) que influiram nos processos de reativação posteriores e ainda hoje são palcos de manifestações da tectônica ressurgente (Hasui 1990).

A Figura 14 mostra a distribuição dos epicentros na região amazônica e uma delineação de oito zonas sismogênicas (Mioto 1993), cujas características principais, resumidamente, são:

1. A Zona Sismogênica de Boa Vista tem epicentros concentrados a sul e sudeste do Gráben de Tacutu e associa-se a uma faixa onde se reconhece a incidência de processos tectônicos, magmáticos e sedimentares do PréCambriano (faixa de justaposição dos blocos Caroni/Alto Orinoco e Maecuru, que envolve a Sutura Guiana Central e o Cinturão Granulítico Guiana Central), do Proterozóico Médio (Lineamento Tacutu), do Mesozóico (magmatismo básico e alcalino, Bacia de Tacutu) e cenozóicos (ver capítulo anterior, área do nordeste de Roraima). 


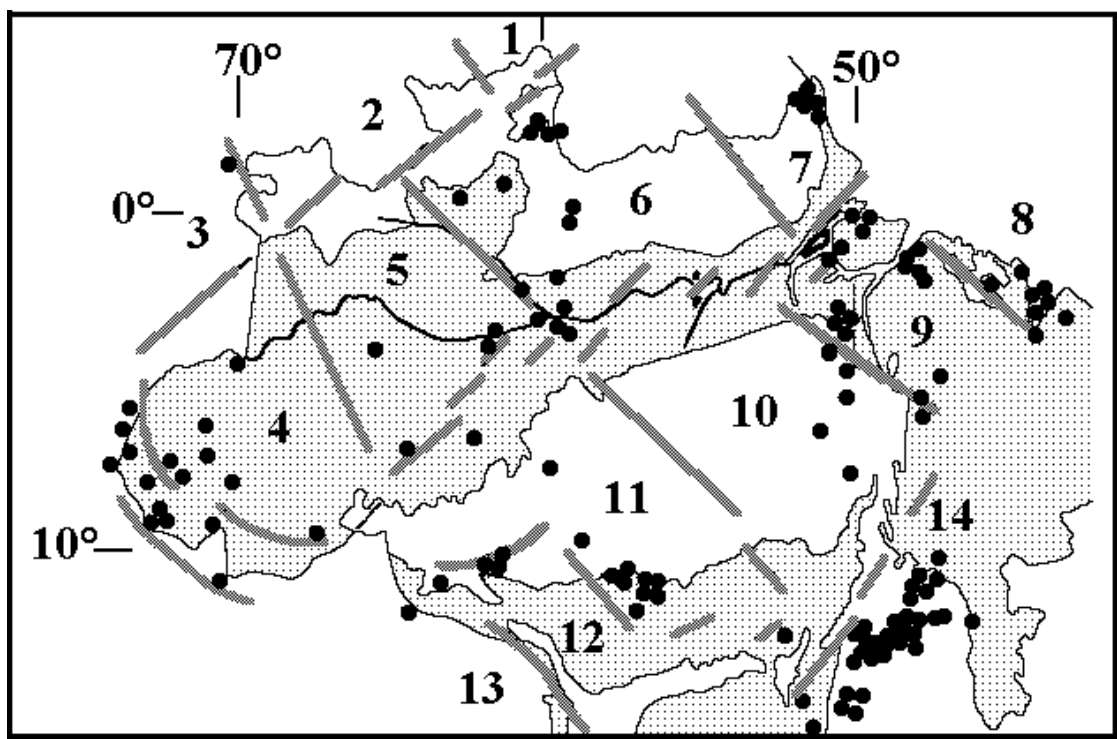

Figura 14: Distribuição dos epicentros da região amazônica. Círculos pretos: epicentros. Traços em cinza: suturas. Pontilhado: coberturas fanerozóicas. Zonas sismogênicas: (1) Boa Vista, (2) Manaus, (3) Belém, (4) São Luís, (5) Itacaiúnas, (6) Porangatu, (7)Aripuanã, e (8) Cruzeiro do Sul. Baseado em Mioto (1993).

Figure 14: Spatial distribution of epicenters in the Amazonic Region. Dots: epicenters. Gray lines: sutures. Stippled: Phanerozoic sedimentary covers . Seismogenic zones: (1) Boa Vista, (2) Manaus, (3) Belém,

(4) São Luís, (5) Itacaiúnas, (6) Porangatu, (7)Aripuanã, (8) Cruzeiro do Sul. After Mioto (1993).

2. A Zona Sismogênica de Manaus enfeixa os epicentros no entorno da confluência dos rios Negro/ Solimões/Amazonas e seu evento mais importante foi o de Codajás (5/8/1983, magnitude 5,5). Essa zona coincide com as faixas de justaposição dos blocos Maecuru, Japurá, Juruena e Araguacema (que envolve a articulação das suturas Rio Negro, Médio Tapajós, Baixo Amazonas e Madeira); tais faixas foram palcos de reativações posteriores no Proterozóico Médio (Lineamento Abacaxis e Serra do Cachorro), Paleozóico (Arco de Purus), Mesozóico (soleiras de diabásio) e Cenozóico (ver capítulo anterior, áreas do centro-oeste e leste do Amazonas).

3. A Zona Sismogênica de Belém é marcada pelos epicentros da região de Belém e da foz dos rios Amazonas e Tocantins e seus sismos mais destacados foram os de Belém (12/1/1970, intensidade 4,5) e do nordeste da Ilha do Marajó (2/8/77, intensidade 4,8). Essa zona coincide com as faixas de justaposição dos blocos Belém e São Luís (envolvendo a articulação das suturas Amapá e Gurupi), que acomodaram movimentações posteriores no Paleozóico, Mesozóico (Bacia do Marajó, Villegas 1992) e Cenozóico (ver capítulo anterior, área do norte do Pará).

4. A Zona Sismogênica de São Luís abarca o norte do Maranhão, marcando-se pelos eventos da área da Baía de São Marcos, nas margens do Itapicuru, na borda oeste da Bacia de São Luís em Alcântara (Mioto 1993, Ferreira Jr. 1996). Essa zona coincide com a faixa de justaposição dos blocos Belém e São Luís (envolvendo a Sutura Gurupi), que teve reativações no Proterozóico (intrusivas ácidas), Paleozóico e Mesozóico (Arco
Ferrer-Urbano Santos, bacias costeiras; Igreja 1992), e Cenozóico (ver capítulo anterior, área do noroeste do Maranhão).

5. A Zona Sismogênica de Itacaiúnas estende-se do centro-leste do Pará ao centro-oeste do Maranhão, envolvendo a Serra dos Carajás, e seu evento mais importante foi o de Redenção (12/11/1980, intensidade 4,7). Essa zona coincide com a faixa de justaposição dos blocos Belém e Araguacema (inclui a Sutura Central do Pará e o Cinturão Granulítico Bacajá), que sofreu reativações no Proterozóico Médio (Lineamento Bacajá), Paleozóico (extremidade oeste do Arco de Xambioá), Mesozóico (magmatismo básico) e Cenozóico (ver capítulo anterior, área do nordeste de Tocantins e sul do Maranhão).

6. A Zona Sismogênica de Porangatu (Hasui \& Mioto 1988) abrange o sul de Tocantins e grande parte de Goiás e seus eventos tiveram intensidades de 3,0 a 3,7. Essa zona coincide com o domínio da Estrutura em Quilha Brasil Central (Hasui et al. 1994), que sofreu reativações no Proterozóico (faixas Brasília e Paraguai), Paleozóico (área de interligação entre as bacias do Parnaíba e Paraná), Mesozóico (magmatismo básico, falhamentos) e Cenozóico (Ilha do Bananal).

7. A Zona Sismogênica de Aripuanã abrange partes de Rondônia e Mato Grosso e nela se registrou o maior evento sísmico do País (Serra do Tombador, MT, 31/ $1 / 1995$, intensidade 6). Essa zona coincide com a faixa de justaposição dos blocos Juruena e Parecis (inclui a Sutura de Rondônia e o Cinturão Granulítico de Rondônia), que sofreu reativações no Proterozóico Médio (magmatismo ácido, grábens Uopiane e Pimenta 
Bueno, lineamento Madeira-Quatorze de Abril), Paleozóico e Mesozóico (Bacia Parecis-Alto Xingu), e Cenozóico (baixada do Guaporé).

8. A Zona Sismogênica de Cruzeiro do Sul é conhecida pelos sismos com hipocentros a 500-700 km de profundidade, que se relacionam com a subducção da Placa de Nazca sob a Placa Sul-Americana, mas existem também sismos rasos, que ainda carecem de definição acurada mas podem representar manifestações intraplaca. Essa zona sismogênica coincide com a faixa da sutura complexa do Acre/Serra do Divisor, que demarca a borda sudoeste do Bloco Juruá (rochas de alto grau expõem-se na Serra do Moa) e movimentações tectônicas do Paleozóico, Mesozóico e Cenozóico.

A Figura 14 mostra, fora dessas zonas sismogênicas, epicentros esparsos, merecendo destacar-se aqueles da região de Monte Alegre-Santarém, indicativos de atividade na zona de junção tríplice referida acima.

\section{DISCUSSÃO}

$\mathrm{Na}$ Amazônia encontram-se as áreas mais elevadas e as maiores extensões de planície do Brasil, cuja coexistência só pode ser melhor entendida a partir da caracterização dos elementos gerados pelos movimentos tectônicos do Cenozóico, sobretudo no Neogeno/Quaternário. O exposto nos capítulos anteriores faz emergir a heterogeneidade do nível de conhecimento neotectônico dessa vasta área e, ao mesmo tempo, indica a enorme complexidade estrutural que se expressa diretamente no quadro morfo-litoestrutural atual.

Apesar dessas dificuldades, pode-se avançar na interpretação regional. A discussão das informações em termos evolutivos, dentro da lógica e coerência requeridas pela complexa paisagem dessa imensa região, torna-se necessário lembrar (1) as características fundamentais do substrato neotectônico e (2) o regime tectônico dominante no interior da Placa Sul-Americana através do Cenozóico.

O Cráton Amazônico (Almeida et al. 1976) constitui um trato continental afetado por zonas de cisalhamento geradas em tempos pré-cambrianos muito antigos, que compõem cinturões de cavalgamento e transcorrentes orientados segundo várias direções (NE-SW, NW-SE, N-S, E-W, ENE-WSW e WNW-ESE). Tais elementos são os traços fundamentais da estruturação crustal que marcam zonas de fraqueza potencialmente favoráveis a reativação no desenvolvimento dos processos geológicos posteriores (Hasui 1990, J.B.S. Costa \& Hasui 1991, Hasui et al. 1993, Hasui 1996). Assim, como foi referido no capítulo anterior, elas foram aproveitadas durante o desenvolvimento das bacias extensionais do Proterozóico e, em seguida, na fase de inversão positiva ou fase de deformação das seqüências depositadas; adicionalmente, no Paleozóico e no Mesozóico formaram-se diversas bacias extensionais com arquiteturas fortemente controladas, inclusive nas inversões positivas de áreas das bacias do Solimões e
Parnaíba; por fim, no Cenozóico foram retomadas, controlando a estruturação atual, inclusive a sismicidade.

Em relação à Placa Sul-Americana, sua borda norte é do tipo conservativo, marcado por um cinturão transcorrente dextral que funciona ininterruptamente desde o Paleoceno e possui todos os elementos dos complexos arranjos geométricos do regime direcional. A borda oeste é do tipo colisional e suas estruturas compressivas fundamentais decorreram sobretudo de movimentos do Eoceno e do Mioceno.

Quando das movimentações nessas duas bordas no Terciário Inferior ainda vigia o regime extensional no interior da placa (Evento Sul-Atlantiano); o forte alçamento morfológico gerado a oeste (Cadeia Orogênica Andina) apenas induziu a uniformização dos principais corredores de drenagem, que tiveram seus fluxos desviados para leste (Bemerguy \& J.B.S. Costa 1991). No Oligoceno os movimentos tectônicos continuaram nas duas bordas, enquanto no interior da placa reinava um importante período de estabilidade marcado pelo desenvolvimento do perfil laterítico maturo; nesse quadro de estabilidade generalizada registram-se apenas algumas exceções, a exemplo da zona transcorrente situada na região do baixo Amazonas, que se manteve ativa ao longo do Cenozóico.

A partir do Mioceno começou a incidir no interior da placa o regime direcional dextral que responde pelo quadro neotectônico e não há mudanças na natureza dos movimentos das bordas da Placa Sul-Americana.

Assim, marcam-se dois pontos básicos: (1) o quadro neotectônico da Amazônia instalou-se em um segmento crustal fortemente anisotrópico e descontínuo e sua complexidade se deve à participação efetiva das estruturas preexistentes e ao próprio caráter do regime direcional, e (2) o quadro neotectônico da Amazônia não tem relação direta com o desenvolvimento do Cinturão Orogênico Andino e nem com o Cinturão Transcorrente do Caribe.

Nesse contexto é fácil entender porque no Terciário Superior a região litorânea, as regiões nordeste de Roraima, sul do Maranhão e nordeste de Tocantins experimentavam transtensão gerando bacias com formas e dimensões variadas, enquanto em outras regiões (centrooeste do Amazonas, oeste, sudeste e nordeste do Pará, e noroeste do Maranhão) incidia transpressão formando, em alguns casos, verdadeiros cinturões de cavalgamento se for considerada a dimensão da área afetada; há também casos de clássicos cinturões transcorrentes (regiões dos baixos cursos dos rios Amazonas e Madeira, "Bico do Papagaio", serra Pacaraima etc.).

Após o período de estabilidade do Pleistoceno Médio, marcado pelo desenvolvimento do perfil laterítico imaturo, foram retomados os movimentos transcorrentes dextrais. Algumas regiões submetidas a transpressão passaram a experimentar transtensão (Manaus e adjacências, nordeste do Pará, noroeste do Maranhão, baixo Tapajós, baixo Trombetas, e Boa Vista 
e adjacências), umas mantiveram-se sob transtensão (nordeste do Pará, noroeste do Maranhão, leste do Amapá, nordeste de Tocantins e sul do Maranhão), e outras continuaram sob transpressão (centro-oeste do Amazonas e Serra dos Carajás). Tais condições são comuns no regime direcional, e as junções tríplices das regiões oeste e centro-norte do Pará se ajustam a esse quadro, como se representassem reativações de feições preexistentes, talvez mesozóicas. Contudo, essas junções, bem como o extenso segmento distensivo que controla a Serra do Estrondo, requerem investigações de maior detalhe para serem devidamente entendidas.

Quanto à evolução da paisagem no Terciário Superior alguns aspectos podem ser destacados:

1. Deu-se a individualização da Serra do Estrondo como divisor de águas dos rios Araguaia e Tocantins.

2. Formaram-se as serras dos Carajás e do Tiracambu,alcançando altitudes de 800 e $500 \mathrm{~m}$, respectivamente.

3. Houve o desenvolvimento de anomalias em cotovelo na área de confluência dos rios Araguaia e Tocantins, resultando na feição denominada "Bico do Papagaio".

4. O "Mar Pirabas" avançou por extensão aproximada de $150 \mathrm{~km}$ no continente (região nordeste do Pará), resultando em enormes modificações da linha de costa gerada no Evento Sul-Atlantiano. A ampliação do sistema de drenagem nessa região e o gradual recuo do "Mar Pirabas" processaram-se também no Terciário Superior.

5. Deu-se o soerguimento das regiões do baixo Tapajós, baixo Rio Negro e sudoeste do Amazonas, que formaram sistemas de colinas alinhadas na direção NE-SW com altitudes de até $200 \mathrm{~m}$. Essas regiões eram separadas por áreas abatidas e alongadas na direção NE-SW, a exemplo da região do baixo curso do Rio Madeira.

6. Formou-se a Serra Pacaraima em Roraima, atingindo altitudes de $2.000 \mathrm{~m}$. As demais serras adjacentes (Tumucumaque e Imeri), que também se constituem em importantes divisores de águas de várias bacias hidrográficas na fronteira Brasil-Venezuela, devem ter sido formadas nessa mesma época. A região da cidade de Boa Vista também encontrava-se em altitudes de no mínimo $500 \mathrm{~m}$.

7. Delineou-se grande parte da disposição geral verificada atualmente dos principais rios (Amazonas, Branco, Negro, Solimões, Japurá, Juruá, Purus, Tapajós, Xingu, Araguaia e Tocantins).

As principais modificações na paisagem durante $o$ Quaternário são:

1. Formação da Ilha do Marajó e a captura do baixo curso do Rio Tocantins para a direção NE-SW.

2. Formação dos lagos da região noroeste do Maranhão.

3. Instalação dos rios-lagos ou rias interiores do Pará e Amazonas.

4. Captura dos baixos cursos dos rios Xingu e Tapajós para as direções NNW-SSE e NNE-SSW, respectivamente.
5. Formação do pediplano da região de Boa Vista e adjacências.

6. Desnivelamentos no sistema de colinas da região de Manaus e adjacências.

7. Desenvolvimento do padrão trombetiforme do litoral.

\section{CONCLUSÕES}

As investigações neotectônicas na região amazônica realizadas até o presente permitem avançar algumas conclusões principais:

1. Os primeiros movimentos neotectônicos se manifestaram nesse vasto segmento da Placa SulAmericana após o período de estabilidade do Oligoceno, que se marca pelo perfil laterítico maturo.

2. O quadro morfo-lito-estrutural resultou de dois episódios maiores de movimentação, separados por um período de estabilidade no Pleistoceno Médio.

3. Os registros de movimentos recentes em várias áreas, através de estudos sedimentológicos, geomorfológicos, estruturais e sismológicos, e com as mesmas características dos movimentos tectônicos do Mioceno, indicam a continuidade da evolução neotectônica para dentro do Quaternário, sendo que muitas estruturas permanecem ativas.

4. O Cráton Amazônico é um segmento crustal formado por numerosas descontinuidades de naturezas diversas, que, mediante reativações, tiveram papel importante na distribuição e nos tipos dos principais arranjos neotectônicos, assim marcando a incidência da tectônica ressurgente.

5. O quadro neotectônico é decorrente de deformação intraplaca imposta pela atuação de forças de um par conjugado dextral de direção E-W, gerado pela rotação da Placa Sul-Americana para oeste. Não se caracteriza relação com os movimentos que incidem nas suas bordas oeste e norte; de fato, a partir do Mioceno, passou a operar no interior da placa componentes transtensiva e transpressiva orientadas nas direções NE-SW e NW-SE, respectivamente. A complexidade dos aspectos morfo-lito-estruturais estão em perfeita consonância com as variações geométricas e cinemáticas observadas em contextos de regime tectônico direcional.

6. Ainda que exista um controle tectônico geral na geração dos padrões estruturais e cinemáticos, sua diversidade indica partição de movimentação no domínio intraplaca.

Tais conclusões apontam para o fato de que a atividade neotectônica é importante no interior da Placa Sul-Americana pela influência decisiva no modelado da paisagem e pelo potencial de desdobramentos em diversas frentes de aplicação de conhecimentos geológicos, como na prospecção de petróleo, ouro, bauxita e outros bens minerais, na definição de fluxo e acumulação de água e controle de alteração de rochas, no planejamento e desenvolvimento de obras de engenharia, e no planejamento da ocupação do meio físico. 


\section{REFERÊNCIAS BIBLIOGRÁFICAS}

ALMEIDA, F.F.M. 1967. Origem e evolução da Plataforma Brasileira. Rio de Janeiro: DNPM/DGM. Boletim, n. 241.

ALMEIDA, F.F.M. 1986. Distribuição regional e relações tectônicas do magmatismo pós-Paleozóico no Brasil. Revista Brasileira de Geociências, 16 (4):325-349.

ALMEIDA, F.F.M.; HASUI, Y.; NEVES, B.B.B.; FUCK, R.A. 1976. The Upper Precambrian of South America. São Paulo: USP. Boletim IG, $7: 45-80$.

BEMERGUY, R.L. \& COSTA, J.B.S. 1991. Considerações sobre o sistema de drenagem da Amazônia e sua relação com o arcabouço tectono-estrutural. Boletim do Museu Paraense Emílio Goeldi. (Série Ciências da Terra). 3: 75-97.

BEMERGUY, R.L.; COSTA, J.B.S.; HASUI, Y.; BORGES M. S. 1995. Tectônica e paleogeografia da calha do Rio Amazonas. In: SIMPÓSIO NACIONAL DE ESTUDOS TECTÔNICOS, 5. Gramado, 1995. Boletim de Resumos Expandidos... Porto Alegre: SBG/RS e CPGQ/ UFRGS, p 419-420.

BERROCAL, J.; ASSUMPÇÃO, M.; ANTENAZA, R.; DIAS NETO, C.M.; ORTEGA, R.; FRANÇA, H. 1984. Sismicidade do Brasil. São Paulo: IAG/USP e CNEN.

BEZERRA, P.E.L. \& COSTA, J.B.S. 1996. Compartimentação estrutural neotectônica da região de Carolina (MA/TO), Bacia do Parnaíba. In: SIMPÓSIO DE GEOLOGIA DA AMAZÔNIA, 5, Belém, 1996. Boletim de Resumos Expandidos...Belém: SBG/NO, p. 320-322.

BORGES, M.S.; COSTA, J.B.S.; BEMERGUY, R.L.; FERNANDES, J.M.G.; COSTA, M.L.; HASUI, Y. 1995. Evolução neotectônica da região nordeste do Estado do Pará. In: SIMPÓSIO NACIONAL DE ESTUDOS TECTÔNICOS, 5. Gramado, 1995. Boletim de Resumos Expandidos... Porto Alegre: SBG/RS e CPGQ/UFRGS, p. 421-422. (a).

BORGES, M.S.; COSTA, J.B.S.; BEMERGUY, R.L.; FERREIRA JR., C.R.P.; HASUI, Y. 1995. A esculturação da paisagem do litoral norte do Brasil e sua relação com os movimentos neotectônicos do Quaternário. In: SIMPÓSIO NACIONAL DE ESTUDOS. TECTÔNICOS, 5, Gramado, 1995. Boletim de Resumos Expandidos... Porto Alegre: SBG/RS e CPGQ/UFRGS, p. 423-424 p. (b).

COSTA, J.B.S. 1996. A Neotectônica na Amazônia. In: SIMPÓSIO DE GEOLOGIA DA AMAZÔNIA, 5, Belém, 1996. Boletim de Resumos Expandidos... Belém: SBG, p. 35-38.

COSTA, J.B.S.; BORGES, M.S.; BEMERGUY, R.L.; FERNANDES, J.M.G..; COSTA Jr.,P.S.; COSTA, M.L. 1993. A evolução cenozóica da região de Salinópolis, nordeste do Estado do Pará. São Paulo: Editora da UNESP. Geociências, 12 (2): 373-396.

COSTA, J.B.S. \& COSTA, J.A.V. 1996. O quadro neotectônico da região nordeste do Estado de Roraima. In: SIMPÓSIO DE GEOLOGIA DA AMAZÔNIA, 5, Belém, 1996. Boletim de Resumos Expandidos... Belém: SBG/NO, p. 284-286.

COSTA, J.B.S.; HASUI, Y. 1991. O quadro geral da evolução tectônica da Amazônia. In: SIMPÓSIO NACIONAL DE ESTUDOS TECTÔNICOS, 3, Rio Claro, 1991. Boletim... Rio Claro: UNESP e SBG, p. 142-145.

COSTA, J.B.S.; HASUI, Y.; BORGES, M.S.; BEMERGUY, R.L. 1995. Arcabouço tectônico mesozóico-cenozóico da região da calha do Rio Amazonas. São Paulo: Editora da UNESP. Geociências, 13 :2. No prelo.

COSTA. J.B.S.; HASUI, Y.; BORGES, M.S.; BEMERGUY, R.L.; SAADI, A.; COSTA Jr., P.S. 1994. Arcabouço tectônico mesocenozóico da região da calha do Amazonas. In: SIMPÓSIO DE GEOLOGIA DA AMAZÔNIA, 4, Belém, 1994. Boletim de Resumos Expandidos... Belém: SBG, p. 47-50.

COSTA, J.B.S.; IGREJA, H.L.S.; BORGES, M.S.; HASUI, Y.1991. O quadro tectônico regional do Mesozóico na região Norte do Brasil. In: SIMPÓSIO DE GEOLOGIA DA AMAZÔNIA, 3, Belém, 1991. Anais... Belém: SBG, p. 166-178.

COSTA, M.L. 1991. Aspectos geológicos dos lateritos da Amazônia. Revista Brasileira de Geociências. 21 (12): 146-160.

CUNHA, F.M.B. 1991. Morfologia e neotectonismo do Rio Amazonas. In: SIMPÓSIO DE GEOLOGIA DA AMAZÔNIA, 3, Belém, 1991. Anais... Belém: SBG/NO, p. 193-210.

EIRAS, J.F.\& KINOSHITA, E.M. 1988. Evidências de movimentos transcorrentes na Bacia do Tacutu. Rio de Janeiro: Petrobrás. Boletim de Geociências, 2 (2/4):193-208

FERNANDES FILHO, L.A.; COSTA, J.B.S.; COSTA, M. L.1995. Bacia de Manaus: uma estrutura pull-apart do Quaternário. In: SIMPÓSIO NACIONAL DE ESTUDOS TECTÔNICOS, 5. 5. Gramado, 1995. Boletim de Resumos Expandidos... Porto Alegre: SBG/RS e CPGQ/ UFRGS, p. 419-420.

FERREIRA Jr., C.R.P. 1996. Neotectônica na Bacia de São Luís. Belém: CG/UFPA. Dissertação (Mestrado).

FERREIRA Jr., C.R.P; COSTA, J.B.S; BEMERGUY, R.L.; HASUI, Y. 1996. Neotectônica na área da Bacia de São Luís. São Paulo: Editora da UNESP. Geociências. 14 :1. No prelo.

FRANCO, E.M.S. \& MOREIRA, M.M.M.A. 1977. Geomorfologia da Folha SA.19 Içá. Rio de Janeiro: Projeto RADAMBRASIL. (Levantamento de Recursos Naturais), 14:125-180.

FRANZINELLI, E.; IGREJA, H.L.S. 1990. Utilização do sensoriamento remoto na investigação da área do baixo Rio Negro e Grande Manaus. In:. SIMPÓSIO BRASILEIRO DE SENSORIAMENTO REMOTO, 6. Anais... 3 :641-648.

FRANZINELLI, E. \& PIUCI, J. 1988. Evidências de neotectonismo na Bacia Amazônica. In: CONGRESSO LATINO-AMERICANO DE GEOLOGIA, 7, Belém, 1988. Anais... Belém, SBG, p. 80-90.

HASUI, Y. 1990. Neotectônica e aspectos fundamentais da tectônica ressurgente no Brasil. In: WORKSHOP SOBRE NEOTECTÔNICA E SEDIMENTAÇÃO CENOZÓICA CONTINENTAL NO SUDESTE BRASILEIRO, Belo Horizonte, 1990. Anais ...Belo Horizonte: SBG/MG, p.1-31.

HASUI, Y. 1996. Evolução geológica da Amazônia. In: SIMPÓSIO DE GEOLOGIA DA AMAZÔNIA, 5, Belém, 1996.Boletim de Resumos Expandidos... Belém: SBG, p. 31-34.

HASUI, Y.; COSTA, J.B.S.; HARALYI, N.L.E. Estrutura em quilha Brasil Central, uma feição fundamental na Geologia de Goiás e Tocantins. São Paulo: Editora da UNESP. Geociências, 13 (2):463-497.

HASUI, Y.; HARALYI, N.L.E.; COSTA, J.B.S. Megaestruturação précambriana do território brasileiro baseada em dados geofísicos e geológicos. São Paulo: Editora da UNESP. Geociências, 12 (1):732.

HASUI, Y.; HARALYI, N.L.E.; SCHOBBENHAUS, C. Elementos geofísicos e geológicos da região amazônica: subsídios para o modelo geotectônico. In; SYMPOSIUM AMAZONICO, 2, Manaus, 1984. Anais... Brasília: DNOM, p. 129-147.

IGREJA, H.L.S. 1992. Aspectos tectono-sedimentares do Fanerozóico do nordeste do Estado do Pará e noroeste do Maranhão, Brasil. Belém: CG/UFPA. Tese (Doutorado).

MIOTO, J.A. 1993. Sismicidade e zonas sismogênicas do Brasil. Rio Claro: IGCE/UNESP. Tese (Doutoramento), $2 \mathrm{v}$.

OLIVEIRA, A.A.B.; PITTHAN, J.H.L.; GARCIA, M.G.L. 1977. Geomorfologia da Folha SB.19 Juruá. Rio de Janeiro: Projeto RADAMBRASIL, (Levantamento de Recursos Naturais), 15 : 91142.

SANTOS, J.O.S. 1984. A parte setentrional do Cráton Amazônico (Escudo das Guianas) e a Bacia Amazônica. In: C. Schobbenhaus, D.A. Campos, G.R. Derze, H.E. Asmus (Coordenadores), Geologia do Brasil. (Texto explicativo do Mapa Geológico do Brasil e da área oceânica adjacente incluindo depósitos minerais, escala 1:2.500.000). Brasília: DNPM, p. 57-92.

SCHOBBENHAUS, C. \& CAMPOS, D.A. 1984. A evolução da Plataforma Sul-Americana no Brasil e suas principais concentrações minerais. In: C. Schobbenhaus, D.A. Campos, G.R. Derze, H.E. Asmus (Coordenadores), Geologia do Brasil. Texto explicativo do Mapa Geológico do Brasil e da área oceânica adjacente incluindo depósitos minerais, escala 1:2.500.000. Brasília: DNPM, p. 9-56.

STERNBERG, H.O.R.1950. Vales tectônicos na planície Amazônica?. Revista Brasileira de Geografia, 12 (4): 3-26.

STERNBERG, H.O.R. 1953. Sismicidade e morfologia na amazônia brasileira. Anais da Academia Brasileira de Ciências, 25 (4):443453.

TRAVASSOS, W.A.S. \& BARBOSA FILHO, C.M. 1990. Tectonismo terciário na área do Rio Tapajós, Bacia do Rio Amazonas. Rio de Janeiro: Petrobrás., Boletim de Geociências,4 (3):221-340.

TRUCKENBRODT, W.; KOTSCHOUBEY, B.; SCHELLMANN, W. 1991. Composition and origin of the clay cover on North Brazilian laterites. Geologische Rundschau, 80 :591-610.

VILLEGAS J. M.1994. Geologia Estrutural da Bacia do Marajó. Belém: CG/UFPA. Tese (Mestrado). 